\title{
Revisiting Rwanda's agricultural intensification policy: benefits of embracing farmer heterogeneity and crop-livestock integration strategies
}

\author{
Sung Kyu Kim ${ }^{1} \cdot$ Fiona Marshall ${ }^{1,2} \cdot$ Neil M. Dawson ${ }^{3,4}$ \\ Received: 17 December 2020 / Accepted: 10 November 2021 / Published online: 31 January 2022 \\ (c) The Author(s) 2022
}

\begin{abstract}
The government of Rwanda is promoting agricultural intensification focused on the production of a small number of targeted commodities as a central strategy to pursue the joint policy goals of economic growth, food security and livelihood development. The dominant approach to increase the productive capacity of the land, crops and animal resources has been through large-scale land consolidation, soil fertility management, and the intensive use of biotechnology and external inputs. However, evidence has shown that many Rwandan farmers, who employ various strategies and mixed farming practices based on their specific economic, social, and environmental circumstances, face difficulties adopting the singular prescribed approach to become more productive, modern commodity producers. To empirically explore diversity in smallholders' strategies and their contributions to livelihoods and compatibility with the recent intensification policies, we conducted household surveys and in-depth qualitative interviews in rural and peri-urban zones in Rwamagana district in Eastern Rwanda. Our analysis demonstrates how the dominant approach to intensification and specialisation overlooks the heterogeneity and dynamic nature of smallholder strategies. Moreover, our findings illustrate that a comprehensive understanding of farmer heterogeneity is necessary to explain the critical disjuncture between the government's vision of modern agriculture and the ability of many smallholders to engage with this agenda and may inform opportunities to adapt policies to better align productivity goals and livelihoods. In doing so, we contribute to debates about the current framing of intensification policy that promotes Green Revolution technologies and emphasise alternative pathways for more inclusive and resilient agricultural development in sub-Saharan Africa.
\end{abstract}

Keyword Agricultural intensification · Crop-livestock integration · Green Revolution for Africa · Mixed farming · Pathways approach $\cdot$ Rwanda

Sung Kyu Kim

s.k.kim@sussex.ac.uk

Fiona Marshall

f.marshall@sussex.ac.uk

Neil M. Dawson

neil.dawson@uea.ac.uk

1 Science Policy Research Unit, University of Sussex Business School, Falmer, Brighton BN1 9SL, UK

2 The Sussex Sustainability Research Programme, University of Sussex, Falmer, Brighton BN1 9SL, UK

3 School of International Development, University of East Anglia, Norwich NR4 7TJ, UK

4 European School of Political and Social Sciences (ESPOL), Lille Catholic University, Lille, France

\section{Introduction}

There is a renewed call for agricultural investment and production intensification worldwide, especially in subSaharan Africa, where the agriculture sector is a significant contributor to the national economy and provides work and food for most people living in poverty. Proponents of the Green Revolution (GR) promote increasing growth in food productivity through genetic improvements of crops and livestock, greater public investments in agriculture, closer integration of market value-chains and international trade (Conway, 1998; World Bank, 2008). Rapid intensification and commodification processes in parts of Asia and Latin America have indeed generated remarkable production increases in the major staple crops such as wheat and rice which were associated with strong national economic 
growth and increases in average incomes and living standards which contributed to the number of people living in extreme poverty fall progressively in the last sixty years (Pingali, 2012). In sub-Saharan Africa, this form of intensification is also widely rationalised as an essential strategy to support economic development and poverty reduction and to meet national demands for food in the face of rapid population increase (The Abuja Summit, 2006; The Malabo Summit, 2014). Governments, international agencies, multinational agri-food corporations and philanthropic donors have designed and implemented policies in pursuit of a new Green Revolution through programmes such as the Alliance for a Green Revolution in Africa (AGRA) and the East Africa Dairy Development (EADD) (Ariga et al., 2019; Otsuka \& Muraoka, 2017). A further key aim of intensification policies is to benefit the millions of smallholder families whose livelihoods rely to a significant degree on farming (Vanlauwe et al., 2014).

However, some scholars have argued and cautioned against replicating a GR strategy without recognising and correcting the limitations and unintended consequences, particularly for smallholders focused on subsistence or mixed farming geared towards local economies (McMichael, 2009; Moorsom et al., 2020). Agricultural intensification can take many forms (Pretty et al., 2018), and a focus on a single blueprint GR strategy for intensification can limit attention to the inevitable social, economic and environmental trade-offs (Struik et al., 2014). This has been an important area of study for scholars of agrarian change who have followed colonial and postcolonial agricultural policies in sub-Saharan Africa over many years (Bates, 1987; Mkandawire, 2014; Patel, 2013), cautioning against imposed efforts to bring about rapid commercialisation because rural livelihoods are diverse and driven by values and aims beyond short-term income maximisation (Ellis, 1993; Scoones, 2009). Evidence from the implementation of Green Revolution policies globally has revealed that many initiatives have not been inclusive or widely taken up by smallholders and have resulted in increasing inequality and negative environmental impacts (Bernstein, 1990; Evenson \& Gollin, 2003; Griffin, 1979; Wanmali \& Bayliss-Smith, 1984). A key reason for GR policies having been less successful in generating inclusive development and livelihood support has been identified as an over emphasis on a singular model of 'technologicallydriven' intensification against other forms of innovation that may build on farmers' varying strategies and capacities (Altieri \& Toledo, 2011; Brookfield, 1984, 2001). Examples of negative impacts incurred by smallholders as a result of GR policies include: loss of traditional practices and agricultural deskilling (Stone et al., 2007); restrictions on choices for farmers' experimentation and innovation (Parrott \& Marsden, 2002); inflexibility of high-yielding varieties' and associated agricultural input packages (Pearse, 1980); food insecurity and loss of resilience against shocks caused by markets and severe weather due to over-reliance on export crops (Pinstrup-Andersen and Hazell, 1985); land tenure insecurity caused by new property rights regimes and land consolidation to accommodate intensive production (Huggins, 2009); lack of provision and counter-measures to gender-biased intensification technologies and uneven access to conventional extension services for women farmers (Djurfeldt et al., 2019); and a loss of control due to the top-down governance through which many policies have been implemented (Ansoms et al., 2018).

Despite these caveats, the agricultural intensification programme is and will continue to be a central policy tool for national economic development and poverty reduction for many countries in Africa. The case of agricultural development in Rwanda represents an example of this policy approach that has been implemented over more than a decade, countrywide and quite intensively with donor support (GoR, 2017a, 2018e). Moreover, Rwanda's agricultural programmes are similar though perhaps more extreme relative to other countries in sub-Saharan Africa as they have the second-highest population density (525 people per square kilometre) and are subject to acute arable land constraints (World Bank Data, 2020), whilst the majority of the population, especially the poor, depend heavily on farming for livelihoods. The transformation of the agriculture sector is thus a crucial stepping stone for economic growth and development in Rwanda.

In this paper, we argue that it is essential to understand the processes through which agricultural transformations unfold for specific types of farming households, i.e. from mixed livestock and multi-crop farming to commercialbased intensive production; and that this will provide an important foundation for devising more inclusive and supportive development measures which are appropriate to the requirements of different types of smallholder farmers. To do so, we must first understand the underlying patterns of crop-livestock integration, which is the predominant form of farming for smallholders in Rwanda. Various forms of mixed farming will give rise to different opportunities for and multiple paths to intensification and a set of associated synergies and trade-offs which will impact on farmers' livelihoods. An enhanced understanding of these issues could help explain why some farmers engage better with the government's policy whilst others cannot. Thus, the overarching aim of this paper is to explore the diversity of farmers' circumstances and strategies and how those are impacted by the implemented policies promoting transformation towards "technology-intensive agriculture with a commercial focus" (GoR, 2018c), thus highlighting opportunities and challenges of various alternative pathways of agricultural growth and development. 


\section{Smallholder farming and agricultural policies in Rwanda}

In the last two decades, the proportion of people living under the poverty line (real consumption per adult equivalent of RWF 159,375 per year, which is about USD 159) has decreased steadily from 58.9 percent (2000/1) to 56.7 (2005/06), and 44.9 percent (2010/11) to 39.1 (2013/14), and more recently to 38.2 percent (2016/17) (GoR, 2011, 2015a, $2018 b$ ). However, the poverty rate in rural areas is nearly three times higher than in urban areas, with 43.1 and 15.8 percent, respectively (GoR, 2018b). Rwandan farmers face acute land constraints due to rising population density and limited economic activities outside of farming (Reyntjens, 2018; Verwimp, 2002). The share of land used for agriculture increased from 53 percent in 1961 to 73 percent in 2016 as a result of land expansion programmes such as reclamation and radical terrace building (FAOSTAT, 2020). However, the average size of farmland per household has steadily decreased over the years and rural land distribution is highly skewed. The most affluent (about a quarter of all households) control 70 percent of the country's agricultural land (i.e. averaging roughly two hectares, but some of the urban elites hold over 20 hectares); whereas one third of households control 25 percent (average landholding of 0.60 hectares); the remaining one third of the households controls only six percent (average holdings of 0.11 hectares); whilst about ten percent of the households are landless (LandLinks, 2017). The percentage of households cultivating at least one plot of land remains very high, over 90 percent at the country level, but even higher over 95 percent amongst rural households (GoR, 2011). The distribution of cultivated land size demonstrates that the majority of farmers are smallholders, with 45 percent cultivating less than 0.30 hectares (GoR, 2011). Evidence from similar mixed production systems in East and Southern Africa indicates that this agricultural plot size is economically non-viable without supplementary off-farm earnings or input subsidies (Dixon et al., 2001).

Thus, many smallholder farmers adopt low external inputs and make use of multi-functional and supportive services derived from crop and livestock production, such as multi-purpose legumes for animal feeding and soil fertility management (Droppelmann et al., 2017), along with highly diversified and labour-intensive practices to meet the family's essential needs (Byiringiro \& Reardon, 1996; Jayne et al., 2014). Farmers typically inter-crop several varieties of staple crops together with trees and forage grass to provide fruits, green manure, and animal feeding throughout the cropping seasons. The staple crops grown vary widely, but most farmers cultivate beans ( 90 percent), maize ( 42 percent), sorghum (13 percent), bananas ( 28 percent), sweet potatoes ( 45 percent) and cassava (40 percent) on multiple plots (GoR, 2012).
Most farmers also own some livestock: 47 percent keep cattle, 24 percent keep pigs, 53 percent keep goats and 45 percent keep chickens (GoR, 2011). Farm animal manure is used extensively in soil fertility management as it is one of the most important and often the sole input of fertiliser for smallholders in Rwanda (Kim et al., 2013). For instance, in agricultural season A in 2020, ${ }^{1}$ while over 60 percent of farmers applied organic manure ( 63 by small- and 69 by large-scale farmers), 34 percent used chemical fertiliser with a considerably low application by smallholders ( 33 percent) than largescale farmers ( 84 percent) (GoR, 2020). Such practices have been shown to conserve resources, improve nutrient recycling and provide better soil structure (Clay et al., 1998; Drechsel et al., 1996). However, despite these beneficial practices, continuous cultivation without fallow periods or an insufficient amount of additional inputs of nutrients and soil organic matter tends to deplete soil fertility and structure over time (Lal, 2015). In Rwanda, the growing demands for rural settlement and continuous food cultivation are leading causes of land erosion and soil degradation on steep hillsides and mountain areas, a major concern for the government and farmers alike (GoR, 2018c; Kuria et al., 2019).

Successive governments have treated low yields of commercial crops as a problem requiring a technological solution to reorient and intensify commodity production (Ansoms, 2008). According to the Rwanda Vision 2020: “[c]urrently, Rwanda's land resources are utilized in an inefficient and unsustainable manner" (in economic terms of efficiency and profitability) and "Rwandans can no longer subsist on land and ways and means need to be devised to move the economy into the secondary and tertiary sectors," and "[t]his can only happen through the production of high value crops and modern livestock management" (GoR, 2000). The "importance of agro-processing and technology-driven agriculture with a commercial focus" continues to be the centrepiece of the framing of the national strategy and Vision 2050 for agricultural transformation (GoR, 2018e).

Due to the cross-cutting nature of agricultural and rural development and poverty reduction strategies, the policies for agricultural intensification, rural transformation and social protection overlap considerably. For instance, subsidised distribution of improved seeds and fertilisers under crop intensification programme is exclusively channelled to the land consolidation programme, allowing synchronised

\footnotetext{
${ }_{1}$ Rwanda has distinct precipitation patterns which allow for two rounds of cropping and harvest (or three if irrigated). The first rainy season starts from September to January the next year (Season A), followed by a brief dry period from January to February. The next rainy season usually starts from March to July (Season B). Finally, from July to early September (Season C), a more extended dry season completes the farm production cycle, where irrigation facilities permit.
} 
large-scale crop production on fragmented parcels (GoR, 2005, 2007). Moreover, participating smallholders are organised in cooperatives whilst local government extension agents provide advice and coordinate subsidised inputs distribution. Similarly, selections of crops are predetermined according to regional crop specialisation and agroecological conditions. For instance, land reclamation and rehabilitation for steep slope terracing are promoted for corn and potato productions and irrigation for rice production in marshlands (GoR, $2018 \mathrm{c}$ ). These programmes are often accompanied by rural (re)settlement or villagisation (imidugudu), which facilitate clustering of rural dwellings for a more cost-efficient organisation and public infrastructure and services delivery (GoR, 2018f). Similarly, national promotion of livestock distribution and development is carried out through the "one cow per poor family" (Girinka) that distributes a heifer (or goats) according to households' poverty profiles as part of the social protection programme (GoR, 2013, 2018a).

Given the challenge of transforming the agricultural sector in Rwanda, the government's concerted strategy and policy approach has yielded significant improvements in macroeconomic growth and increases in certain commodity crops and livestock productions (Booth and GoloobaMutebi, 2014). For instance, the government's investment in the commercial horticulture sector has seen rapid expansion in export markets, making up over 50 percent of nontraditional exports ${ }^{2}$ and raising export revenue from USD 5 million in 2005 to USD 25 million in 2018 (GoR, 2021). Whilst we fully acknowledge these remarkable achievements, what remains critically overlooked is the policy objective of achieving the balance between productivity growth and income distribution and its micro-level impacts on farmers and their farm productions and livelihoods. It is towards these twin policy objectives that this paper focuses on assessing its achievements and challenges. Despite almost two decades of concerted agricultural intensification interventions, the empirical evidence for productivity improvements, farmers' perspectives and rural development indicators reveal contested and patchy results (Ansoms et al., 2018; Dawson et al., 2016; Huggins, 2014; Ingelaere, 2014). For instance, some of the government priority crops such as maize (included under the Crop Intensification Programme) have reportedly achieved strong average yield growth over the years - averaging 4 percent from 2015 to 2019 in seasons A (GoR, 2015b, 2016, 2017b, 2018d, 2019) - and have been considered a success by the government and the international partners (World Bank, 2014). However, other

\footnotetext{
$\overline{2}$ Traditional agricultural export crops are coffee, tea, and pyrethrum, whereas non-traditional crops consist of horticulture products (fruits, nuts, vegetables, cut flowers) and animal products (meat, dairy, hides, silk, honey, etc.).
}

researchers indicate a much more modest increase in growth rate than the government's official figures suggest, which points to the difficulties in establishing accurate agricultural data and the perverse incentive to overestimate harvest figures by the local government to conform to annual performance targets (Heinen, 2021), which may, in turn, lead to discrepancies between datasets used in estimating agricultural yields (Desiere et al., 2016). Other studies have cautioned against the government's over-reliance on macro-level statistics to report success - and the need to understand the multiple dimensions of poverty and the diverse and complex processes of development, and to pay attention to rural heterogeneity in people's livelihoods and lived experiences (Dawson, 2015). Moreover, the arguments over whether the government's vision is inclusive towards (and if it adequately reaches) its vulnerable populations and the extent to which it considers what types of farmers will benefit or lose from intensification policies remain unresolved (Ansoms, 2008; Clay, 2018; Van Damme et al., 2014).

In this article, we critically assess Rwanda's agricultural intensification and commercialisation policy agenda as a case study. In particular, we explore the extent to which the promoted forms of intensification consider the diverse and dynamic nature of smallholder farming and livelihood strategies. We pay specific attention to whether and how the implemented policies are able to realise opportunities for supporting crop-livestock integration in ways that foster inclusive growth in agricultural production. We present empirical mixed-methods research in Rwanda to demonstrate how integrated approaches to crops and livestock in mixed farming systems can realise production synergies, increase environmental integrity, and serve rural livelihoods by addressing the diverse socio-economic contexts and challenges faced by smallholders. We examine how these insights can enhance understanding of the reasons behind the limited success of long-term agricultural intensification policies and point to constructive adaptations to the framing and implementation of future policies.

\section{Analytical framework}

The theory of induced innovation for agricultural intensification has been utilised in the past to reflect on the drivers for transitions from subsistence to commercial systems (Boserup, 1965; Ruttan \& Hayami, 1984). According to Boserup, rising population density and resulting land scarcity will engender more intensive use of land through increased application of inputs and increased production for markets (Boserup, 1965; McIntire et al., 1992; Pingali \& Rosegrant, 1995). However, over the years, scholars have demonstrated how a multitude of other processes, that are in turn rooted in the underlying social and institutional processes of change 


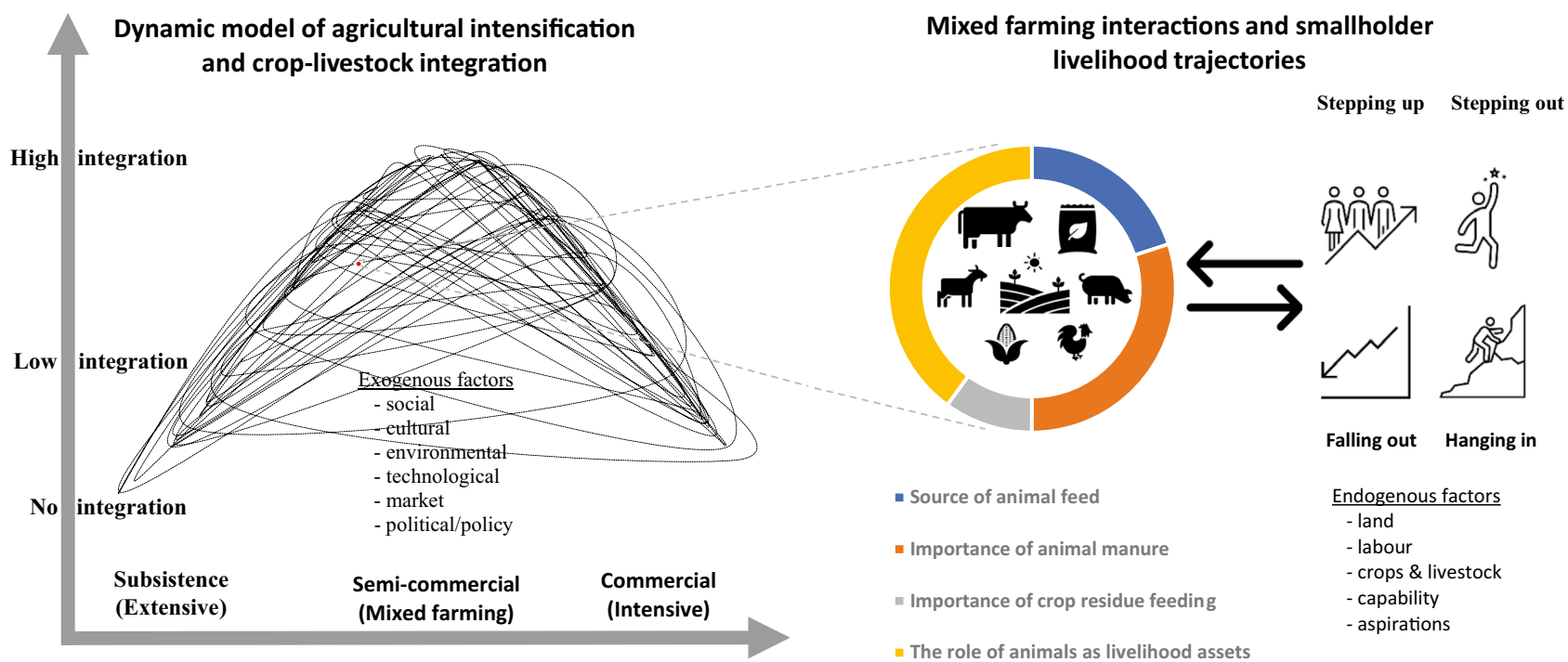

Fig. 1 An analytical framework of Pathways of agricultural intensification, dynamics of mixed farming and smallholder livelihood trajectories. Source: Authors' adapted from Scoones and Wolmer (2002),

(such as the shifting of labour to rural non-farm activities and migration to other rural or urban areas) can also be central to these transition processes (Headey \& Jayne, 2014; Scoones \& Wolmer, 2002). Smallholders' livelihoods are dynamic, and their trajectories are unpredictable and often subjected to sudden, unexpected circumstances related to poverty. Different farmers perceive and approach a given production environment in diverse ways according to their values, interactions and aspirations (Glover et al., 2019). Therefore, an analytical framework for exploring these issues must consider the heterogeneity of smallholder farming, the variability of options and the randomness of people's intrinsic values, capabilities, interests, livelihood circumstances, interacting socio-political processes and multiple potential pathways of change (Scoones \& Wolmer, 2002).

In order to achieve this, we combined insights from Scoones and Wolmer (2002), Pingali and Rosegrant (1995) and McIntire et al. (1992) to develop a framework that takes into account different characteristics associated with farming strategies according to the smallholders' production orientation and livelihood context. A graphic representation of our analytical framework is shown in Fig. 1. First, we begin with a simplified model of agricultural intensification which is represented by a hypothesised (inverted U-shaped) relationship between certain levels of integration and intensification. This suggests that the pressure for intensification tends to progressively shift agricultural practices from
Pingali and Rosegrant (1995), McIntire et al. (1992), FAO (2001), and Dorward et al. (2009)

extensive to more integrated, and leading to, specialised productions (McIntire et al., 1992; Pingali \& Rosegrant, 1995). But the individualised trajectories of changes rarely unfold in a linear, progressive way, and we illustrate the dynamic pathways as unpredictable and seemingly chaotic, reflecting diversity, variability and as well as the randomness of people's intrinsic values, capabilities, interests and livelihood contexts and exogenous circumstances (Scoones \& Wolmer, 2002). In practice, mixed farming can take many forms, and involve varying methods and strategies depending on the type and degree of integration sought and its associated costs and risks (Dorward et al., 2001). Therefore, when we look closely at a particular case (i.e. shown as an enlarged pixel), we pay specific attention to the main interactions within the crop-livestock integrated systems to assess the extent of mixed farming practised: the importance of animal manure to soil fertility management, use of crop residue and forage as source of animal feeding, and the role of livestock and associated products as livelihood assets complementary to crop farming (FAO, 2001). Finally, an adapted version of Dorward et al.'s (2009) framework for dynamic smallholder livelihood trajectories - i.e. falling out, hanging in, stepping up, and stepping out - is used to analyse how different types of Rwandan smallholders have been affected by policies promoting agricultural intensification and react to them vis-à-vis their livelihood aspirations and endogenous factors. 


\section{Methods}

To examine these issues, a mixed methods study consisting of household surveys $\left(\mathrm{n}_{\text {TOT }}=169\right)$ and in-depth qualitative interviews $\left(\mathrm{n}_{\text {tot }}=31\right)$ was undertaken in 2015, involving two communities in rural and peri-urban zones in the district of Rwamagana in the Eastern Province of Rwanda. We selected the district of Rwamagana because of the presence of dairy markets (milk collection centres) and burgeoning agro-food processing industries for animal feed, which are conducive to research the role of intensification and commercialisation processes on agricultural systems and livelihoods. With the promotion of intensified production of crop and livestock based commodities across Rwanda, the findings from Rwamagana are relevant to many other areas of the country and sub-Saharan Africa in general. Rwamagana also comprises areas well connected to the capital, Kigali, for commercial trade, and more remote rural areas for which market connectivity can be challenging. Two sites were selected in this area - one in the peri-urban zone (PU) and the other in the rural zone $(\mathrm{R})$. In this study, peri-urban is characterised as areas on the outskirts of Rwamagana, within a walking radius of $30 \mathrm{~min}$ from the main market centre, but also with a prevalence of highly diversified mixed farming practices in the areas. Household surveys were carried out in peri-urban and rural villages $\left(\mathrm{n}_{\mathrm{PU}}=89, \mathrm{n}_{\mathrm{R}}=80\right)$ to assess the diverse household characteristics such as family composition, means of livelihood and occupations, factors of farming production and asset ownership and access to various resources and services. Households were selected randomly based on a village map constructed through transect walks with the help of village leaders (Chambers, 1994).

Household consumption expenditure and price data are generally used for defining and measuring the living standard. However, collecting these monetary-based data are resource-intensive and often suffer from recall error and difficulty establishing accurate reports in households with more adult members with strong asymmetric intrahousehold dynamic (Beegle et al., 2010). One method that overcomes this problem is an asset index that approximates relative financial standing by using the household survey data on asset ownership, housing characteristics, and household's access to local infrastructure (Sahn \& Stifel, 2003). Principal Component Analysis (PCA) - an exploratory data analysis technique that examines the interrelationships amongst a set of variables - was used to identify the underlying structure and dimensions of the household's ownership of assets and access to essential infrastructure to estimate the relative wealth valuation in the absence of income and expenditure data. Similar to Ansoms and McKay (2010) and Filmer and Pritchett (2001), our asset index was calculated by using a set of 14 variables derived from farming asset ownership, housing characteristics, and household's access to local infrastructure to approximate households' living standard (Tables 1 and 2). The results of the sensitivity analysis (i.e. internal coherence and robustness tests) of the asset indices confirm that the wealth ranking classification of the subgroups is empirically reliable for analysis (Tables 3 and 4).

Following the household survey, in-depth qualitative interviews explored accounts of livelihood strategies and livestockbased asset accumulation amongst different groups of farmers to ascertain how they view and interact with policy and what other changes they encountered in relation to their (dis-) engagement with the intensification agenda. Through comparing differences in their livelihood trajectories, the aim is to explore and broaden our understanding of farmers' mixed farming strategies and how they relate to intensification efforts and aspirations. The primary data comprises 31 in-depth cases, purposely selected from the larger survey sample, to capture the full spectrum of crop-livestock integration practices observed. This included farmers who were recorded to engage in various levels of crop-livestock integration (low, mid, high) and in both peri-urban and rural villages (the list shown in Appendix 1).

\section{Results}

\subsection{General livelihood characteristics in the rural and peri-urban context}

The families and their head of households $(\mathrm{HOH})$ in rural and peri-urban villages have distinctive patterns of agricultural asset ownerships that vary across the wealth groups (Table 5). The landholding data from the rural village show that the poor ( $P_{1-30}$ or the bottom 30 percentiles) have on average the least amount of arable land ( 0.21 hectares), whereas the middle and the highest percentile groups $\left(P_{31-70}\right.$ and $\left.P_{71-100}\right)$ cultivate as much as three to six times more than the poor. Moreover, the poor have a significantly smaller family size, and therefore labour capacity for their farming and incomegenerating activities, compared to the other groups. For most of the poor families, farming alone is not sufficient to meet the household's demands, and they also work in other casual (temporary) labour jobs to supplement their income.

In the peri-urban village, the average plot size of cultivated land is smaller: even amongst the wealthiest families, the average landholding is less than the district average of 0.70 hectares (Table 5). In a peri-urban setting where land is premium, a livelihood solely based on agriculture would likely be insufficient to provide for the family's needs. Also, there is a gender disparity in households' economic standing: 
Table 1 Summary statistics of variables entering the computation of the asset index in the rural village (R)

\begin{tabular}{|c|c|c|c|c|c|c|c|c|}
\hline Variable description & $\begin{array}{l}\text { weight } \\
\left(\mathrm{f}_{1 \mathrm{i}}\right)\end{array}$ & $\begin{array}{l}\text { mean } \\
\left(a^{*}{ }_{i}\right)\end{array}$ & $\begin{array}{l}\text { std.dev } \\
\left(\mathrm{s}^{*}{ }_{\mathrm{i}}\right)\end{array}$ & $\begin{array}{l}\Delta \text { index } \\
\left(\mathrm{f}_{1 \mathrm{i}} / \mathrm{s}{ }_{\mathrm{i}}\right)\end{array}$ & $\begin{array}{l}P_{1-30} \\
(\mathrm{n}=24)\end{array}$ & $\begin{array}{l}\text { Means }^{\alpha} \\
P_{31-70} \\
(\mathrm{n}=32)\end{array}$ & $\begin{array}{l}P_{71-100} \\
(\mathrm{n}=24)\end{array}$ & $\begin{array}{l}p \text {-value } \\
(<0.05)\end{array}$ \\
\hline \multicolumn{9}{|l|}{ (a) farming } \\
\hline own $>0.7$ Hectare of land ${ }^{\delta}$ & 0.283 & 0.350 & 0.480 & 0.590 & 0.083 & 0.313 & 0.667 & 0.00 \\
\hline number of economically active members & 0.269 & 2.163 & 1.049 & 0.257 & 1.625 & 2.219 & 2.625 & 0.00 \\
\hline number of livestock in tropical livestock unit (TLU) ${ }^{\lambda}$ & 0.120 & 0.964 & 0.833 & 0.144 & 0.696 & 1.171 & 0.955 & 0.03 \\
\hline \multicolumn{9}{|l|}{ (b) dwelling } \\
\hline floor material—cement, tile & 0.430 & 0.150 & 0.359 & 1.196 & 0.000 & 0.000 & 0.500 & $\varphi$ \\
\hline wall material—mud brick with cement plaster & 0.993 & 0.188 & 0.393 & 2.528 & 0.083 & 0.156 & 0.333 & 0.14 \\
\hline wall material—timber and mud brick & -0.241 & 0.575 & 0.497 & -0.485 & 0.833 & 0.594 & 0.292 & 0.00 \\
\hline pit toilet/latrine & -0.243 & 0.863 & 0.347 & -0.701 & 0.958 & 0.938 & 0.667 & 0.01 \\
\hline pit toilet/latrine with cement floor slab & 0.292 & 0.113 & 0.318 & 0.918 & 0.000 & 0.031 & 0.333 & 0.00 \\
\hline \multicolumn{9}{|l|}{ (c) durable goods } \\
\hline own radio & 0.085 & 0.563 & 0.499 & 0.170 & 0.375 & 0.594 & 0.708 & 0.02 \\
\hline own mobile telephone & 0.172 & 0.650 & 0.480 & 0.358 & 0.417 & 0.688 & 0.833 & 0.00 \\
\hline own living room suite (furnished) & 0.230 & 0.450 & 0.501 & 0.460 & 0.250 & 0.438 & 0.667 & 0.00 \\
\hline own bicycle & 0.308 & 0.300 & 0.461 & 0.667 & 0.000 & 0.313 & 0.504 & 0.00 \\
\hline \multicolumn{9}{|l|}{ (d) access } \\
\hline connected to electric grid & 0.329 & 0.125 & 0.333 & 0.987 & 0.000 & 0.000 & 0.417 & $\varphi$ \\
\hline use internet at home & 0.379 & 0.063 & 0.244 & 1.556 & 0.000 & 0.000 & 0.208 & $\varphi$ \\
\hline
\end{tabular}

Bartlett's test of sphericity confirms that the correlation matrix is significantly different from the identity matrix $\left(X^{2}=393.831\right.$; $\mathrm{df}=91 ; \mathrm{p}<0.000$ ). The Kaiser-Meyer-Olkin measure of sampling is adequate $(0.688)$. Also, the Cronbach's Alpha statistic confirms that the scale coefficient is reliable (0.679). The percentage of the covariance explained by the first principal component is $26 \% . \alpha$ The EICV3 report in Rwamagana identified $18 \%$ of the population as poor and $12 \%$ extremely poor (GoR, 2011). In this study, we classified the bottom $30 \%$ of the wealth ranking as "low". To keep an even size and distribution of the sub-groups, we stratified the next $40 \%$ as "middle" and the top $30 \%$ as "high"

$\delta$ The mean size of land cultivated per household in the Rwamagana district ( $0.7 \mathrm{ha})$ is used as a reference threshold (GoR, 2011)

$\lambda$ The tropical livestock unit (TLU) conversion factors are: bull $=1.2$; cow $=1.0$; heifer $=0.78$; male calf $=0.38$; female calf $=0.43$; pig $=0.3$; sheep/goat $=0.2 ;$ chicken/rabbit $=0.04$ (Njuki et al., 2011)

$\varphi$ The observations made are only from the most affluent sub-group members. Therefore, the variable perfectly determines the outcome, and no statistical model can hold under this condition

there are proportionally more female-headed households in the poor sub-group than the middle and the highest ranked groups. Households here have greater access to formal, salaried jobs than the rural village due to its proximity to Rwamagana town and the markets. However, although significantly more non-poor families have non-farming jobs, 41 to 57 percent of the better-off families still engage in farming (Table 5). How these different groups approach and practice crop-livestock integration is the focus of the analysis in the following section. We mainly focus on small livestock and dairy production.

\subsection{Dynamics of integrated systems}

In this section, we assess central components of crop-livestock integration: the use of animal manure in soil fertility management, the sourcing of animal feed through grass production and crop residues, and the role of livestock as complementary livelihood assets to crop farming. The extent of integration varied across the study sites and household stratification.

\subsubsection{Importance of organic farm manure}

The government recommends the use of chemical fertiliser, but only one in four households in the rural village reported using it in the year preceding the survey. Amongst those who used it, the low and middle sub-groups of farmers applied less than $31 \mathrm{~kg}$ of fertilisers (of any kind) in total on average that year. The most commonly used local fertilisers are Diammonium phosphate (DAP), urea and compound NPK fertiliser (Nitrogen, Phosphorus and Potassium, respectively). As a point of reference, the recommended rates of fertilisers for maize in Rwanda are $41 \mathrm{~kg}$ of Nitrogen $(\mathrm{N})$ and $46 \mathrm{~kg}$ of Phosphorus pentoxide $\left(\mathrm{P}_{2} \mathrm{O}_{5}\right)$ per hectare (Cyamweshi et al., 2017). In contrast, the wealthier farmers applied on average $89 \mathrm{~kg}$ of chemical fertiliser (a total of all kinds). However, it is important to note that most of the farmers, regardless of the income groups, use fertiliser sparingly by using a seed hole application technique, cf. Mati (2006), and therefore, generalised (blanket) application rates may not be a useful point of comparison. 
Table 2 Summary statistics of variables entering the computation of the asset index in the peri-urban village (PU)

\begin{tabular}{|c|c|c|c|c|c|c|c|c|}
\hline Variable description & $\begin{array}{l}\text { weight } \\
\left(\mathrm{f}_{1 \mathrm{i}}\right)\end{array}$ & $\begin{array}{l}\text { mean } \\
\left(\mathrm{a}^{*}{ }_{\mathrm{i}}\right)\end{array}$ & $\begin{array}{l}\text { std.dev } \\
\left(\mathrm{s}_{\mathrm{i}}\right)\end{array}$ & $\begin{array}{l}\Delta \text { index } \\
\left(\mathrm{f}_{1 \mathrm{i}} / \mathrm{s}{ }_{\mathrm{i}}\right)\end{array}$ & $\begin{array}{l}P_{1-30} \\
(\mathrm{n}=27)\end{array}$ & $\begin{array}{l}\text { Means }^{\alpha} \\
P_{31-70} \\
(\mathrm{n}=35)\end{array}$ & $\begin{array}{l}P_{71-100} \\
(\mathrm{n}=27)\end{array}$ & $\begin{array}{l}p \text {-value } \\
(<0.05)\end{array}$ \\
\hline \multicolumn{9}{|l|}{ (a) farming } \\
\hline own $>0.7$ Hectare of land ${ }^{\delta}$ & 0.250 & 0.191 & 0.395 & 0.633 & 0.037 & 0.114 & 0.444 & 0.00 \\
\hline number of economically active members & 0.168 & 2.225 & 0.938 & 0.179 & 1.926 & 2.086 & 2.704 & 0.00 \\
\hline number of livestock in $\mathrm{TLU}^{\lambda}$ & 0.127 & 0.820 & 1.177 & 0.108 & 0.573 & 0.817 & 1.071 & 0.17 \\
\hline \multicolumn{9}{|l|}{ (b) dwelling } \\
\hline floor material—cement, tile & 0.383 & 0.573 & 0.497 & 0.769 & 0.000 & 0.771 & 0.889 & 0.00 \\
\hline wall material—mud brick with cement plaster & 0.096 & 0.314 & 0.467 & 0.206 & 0.111 & 0.457 & 0.333 & 0.08 \\
\hline wall material—timber and mud brick & -0.301 & 0.213 & 0.412 & -0.731 & 0.593 & 0.086 & 0.000 & 0.00 \\
\hline pit toilet/latrine & -0.341 & 0.596 & 0.494 & -0.690 & 0.889 & 0.771 & 0.074 & 0.00 \\
\hline pit toilet/latrine with cement floor slab & 0.337 & 0.326 & 0.471 & 0.714 & 0.000 & 0.229 & 0.778 & 0.00 \\
\hline \multicolumn{9}{|l|}{ (c) durable goods } \\
\hline own radio & 0.219 & 0.685 & 0.467 & 0.469 & 0.407 & 0.714 & 0.926 & 0.00 \\
\hline own mobile telephone & 0.261 & 0.843 & 0.366 & 0.713 & 0.556 & 0.943 & 1.000 & 0.00 \\
\hline own living room suite (furnished) & 0.265 & 0.764 & 0.427 & 0.620 & 0.407 & 0.857 & 1.000 & 0.00 \\
\hline own bicycle & 0.186 & 0.292 & 0.457 & 0.406 & 0.111 & 0.257 & 0.519 & 0.00 \\
\hline \multicolumn{9}{|l|}{ (d) access } \\
\hline connected to electric grid & 0.352 & 0.607 & 0.491 & 0.716 & 0.185 & 0.657 & 0.963 & 0.00 \\
\hline use internet at home & 0.270 & 0.225 & 0.420 & 0.642 & 0.037 & 0.086 & 0.593 & 0.00 \\
\hline
\end{tabular}

Bartlett's test of sphericity confirms that the correlation matrix is significantly different from the identity matrix $(\times 2=389.744$; $\mathrm{df}=91 ; \mathrm{p}<0.000)$. The Kaiser-Meyer-Olkin measure of sampling is adequate (0.648). Also, the Cronbach's Alpha statistic confirms that the scale coefficient is reliable (0.714). The percentage of the covariance explained by the first principal component is $28 \%$

$\alpha \cdot \delta \cdot \lambda$ are the same as Table 1

Low chemical fertiliser use makes farm animal manure an essential input for soil fertility and crop production (Kim et al., 2013). All farmers use farm animal manure to enrich the soil, but the most significant volume derives from cattle. Therefore, use of cattle manure is considered an essential indicator of a high degree of crop-livestock integration
(Ruthenberg et al., 1980). Collecting manure from smaller animals such as goats and chicken is prevalent in both study sites, but it is more difficult because of lack of permanent housing for goats and free roaming nature of poultry keeping. While the efforts to collect chicken manure may not seem worthwhile, its nutrient contents are higher than the

Table 3 Cross-differences in classification of the Lowest and Highest sub-groups in R village

\begin{tabular}{|c|c|c|c|c|c|c|c|c|c|}
\hline & $\begin{array}{l}\text { base case } \\
\text { pc analysis } \\
\text { (all variables) }\end{array}$ & $\begin{array}{l}\text { case } 1 \\
\text { variables } \\
(\mathrm{b})(\mathrm{c})(\mathrm{d}) \dagger\end{array}$ & $\begin{array}{l}\text { case } 2 \\
\text { variables } \\
(\mathrm{b})(\mathrm{c})\end{array}$ & $\begin{array}{l}\text { case } 3 \\
\text { factor analysis } \dagger \\
\text { (all variables) }\end{array}$ & & $\begin{array}{l}\text { base case } \\
\text { pc analysis } \\
\text { (all variables) }\end{array}$ & $\begin{array}{l}\text { case } 1 \\
\text { variables } \\
(\mathrm{b})(\mathrm{c})(\mathrm{d}) \dagger\end{array}$ & $\begin{array}{l}\text { case } 2 \\
\text { variables } \\
(b)(c)\end{array}$ & $\begin{array}{l}\text { case } 3 \\
\text { factor analysis } \dagger \\
\text { (all variables) }\end{array}$ \\
\hline Low $\neq$ & $100 \%$ & $79 \%$ & $71 \%$ & $96 \%$ & Low & $0 \%$ & $0 \%$ & $8 \%$ & $0 \%$ \\
\hline Middle & $0 \%$ & $21 \%$ & $25 \%$ & $4 \%$ & Middle & $0 \%$ & $21 \%$ & $21 \%$ & $8 \%$ \\
\hline High & $0 \%$ & $0 \%$ & $4 \%$ & $0 \%$ & High $\ddagger$ & $100 \%$ & $79 \%$ & $71 \%$ & $92 \%$ \\
\hline Total & $100 \%$ & $100 \%$ & $100 \%$ & $100 \%$ & Total & $100 \%$ & $100 \%$ & $100 \%$ & $100 \%$ \\
\hline$r_{s}^{*}$ & 1.000 & 0.792 & 0.646 & 0.938 & $r_{s}^{*}$ & 1.000 & 0.792 & 0.646 & 0.938 \\
\hline
\end{tabular}

* All the Spearman's rank correlation coefficients $\left(r_{s}\right)$ are significant at $\mathrm{p}<0.001(n=80)$

$\dagger$ Different sets of variables (Table 1 ) and method (factor analysis) are used to test if the asset-based rankings yield consistent classifications and are reproducible

\# The bold row on the table on the left (Low) holds the poorest as the reference group, and the right-hand side table (High) compares the wealthiest group. Nearly all the households identified as Low and High in the reference group also belong to the same category in the variant cases 1,2 , and 3. That is, the wealth-ranking clusters are consistent and stable across the variant cases 
Table 4 Cross-differences in classification of the Lowest and Highest sub-groups in PU village

\begin{tabular}{|c|c|c|c|c|c|c|c|c|c|}
\hline & $\begin{array}{l}\text { base case } \\
\text { pc analysis } \\
\text { (all variables) }\end{array}$ & $\begin{array}{l}\text { case } 1 \\
\text { variables } \\
(\mathrm{b})(\mathrm{c})(\mathrm{d}) \dagger\end{array}$ & $\begin{array}{l}\text { case } 2 \\
\text { variables } \\
(b)(c)\end{array}$ & $\begin{array}{l}\text { case } 3 \\
\text { factor analysis } \dagger \\
\text { (all variables) }\end{array}$ & & $\begin{array}{l}\text { base case } \\
\text { pc analysis } \\
\text { (all variables) }\end{array}$ & $\begin{array}{l}\text { case } 1 \\
\text { variables } \\
(\mathrm{b})(\mathrm{c})(\mathrm{d}) \dagger\end{array}$ & $\begin{array}{l}\text { case } 2 \\
\text { variables } \\
(\mathrm{b})(\mathrm{c})\end{array}$ & $\begin{array}{l}\text { case } 3 \\
\text { factor analysis } \dagger \\
\text { (all variables) }\end{array}$ \\
\hline Low $\ddagger$ & $100 \%$ & $100 \%$ & $96 \%$ & $96 \%$ & Low & $0 \%$ & $0 \%$ & $0 \%$ & $0 \%$ \\
\hline Middle & $0 \%$ & $0 \%$ & $4 \%$ & $4 \%$ & Middle & $0 \%$ & $7 \%$ & $15 \%$ & $7 \%$ \\
\hline High & $0 \%$ & $0 \%$ & $0 \%$ & $0 \%$ & High $\ddagger$ & $100 \%$ & $93 \%$ & $85 \%$ & $93 \%$ \\
\hline Total & $100 \%$ & $100 \%$ & $100 \%$ & $100 \%$ & Total & $100 \%$ & $100 \%$ & $100 \%$ & $100 \%$ \\
\hline$r_{s}^{*}$ & 1.000 & 0.963 & 0.907 & 0.944 & $r_{s}^{*}$ & 1.000 & 0.963 & 0.907 & 0.944 \\
\hline
\end{tabular}

* All the Spearman's rank correlation coefficients $\left(r_{s}\right)$ are significant at $p<0.001(n=89)$

$\dagger$ The bundles of variables shown in Table 2

$\$$ is the same as Table 3

ruminants' (Barker et al., 2002). Over 60 and 70 percent of the interviewed farmers in the peri-urban and rural villages, respectively, perceived that their land lacked soil nutrients and needed additional inputs such as chemical or organic fertiliser. It is noteworthy that the majority of poor farmers who face severe challenges in soil fertility management lack the means to purchase manure to replenish their soil (95 percent) or worse, could do nothing about it (68 percent). In both study sites, farmers prioritised fertiliser application to selective crops. For instance, farmers who own large tracts of land (over 1 hectare) divided their efforts and resources to grow one major crop (e.g. typically banana or maize and rotate it with beans), and the other half in forage grass but applied fertiliser exclusively for crop production. In contrast, those with lesser arable land typically intercropped maize, beans, sorghum, banana, roots and tubers (e.g. sweet potatoes and cassavas), green peas, and fruits in their kitchen garden.

The rates of chemical fertiliser application are low for all peri-urban farmers: with only 17 and 14 percent of low- and mid-ranked households using it at the time of the survey. In particular, the wealthiest sub-group of farmers applied it the least (only 13 percent) despite having more sizable land and livestock (and financial means) seems to indicate that betteroff peri-urban farmers are not actively pursuing agricultural
Table 5 Livelihood and farming characteristics in the rural and peri-urban settings

\begin{tabular}{|c|c|c|c|c|c|c|c|c|}
\hline \multirow[b]{2}{*}{ Household characteristic } & \multicolumn{3}{|l|}{ Rural } & \multirow[b]{2}{*}{$\ddagger$} & \multicolumn{3}{|c|}{ Peri-urban } & \multirow[b]{2}{*}{+} \\
\hline & $\begin{array}{l}\text { Low } \\
\left(P_{1-30}\right)\end{array}$ & $\begin{array}{l}\text { Mid } \\
\left(P_{31-70}\right)\end{array}$ & $\begin{array}{l}\text { High } \\
\left(P_{71-100}\right)\end{array}$ & & $\begin{array}{l}\text { Low } \\
\left(P_{1-30}\right)\end{array}$ & $\begin{array}{l}\text { Mid } \\
\left(P_{31-70}\right)\end{array}$ & $\begin{array}{l}\text { High } \\
\left(P_{71-100}\right)\end{array}$ & \\
\hline \multicolumn{9}{|l|}{ Family } \\
\hline average family size (pers.) & 3.6 & 5.3 & 5.9 & $*$ & 5.3 & 5.2 & 6.8 & $*$ \\
\hline female headed $(\%)$ & $50 \%$ & $28 \%$ & $33 \%$ & & $44 \%$ & $26 \%$ & $19 \%$ & $*$ \\
\hline \multicolumn{9}{|l|}{ Main occupation of $\mathrm{HOH}(\%)$} \\
\hline Farming & $71 \%$ & $94 \%$ & $96 \%$ & $*$ & $78 \%$ & $57 \%$ & $41 \%$ & $*$ \\
\hline non-farming & $0 \%$ & $3 \%$ & $4 \%$ & & $7 \%$ & $23 \%$ & $52 \%$ & $\dagger$ \\
\hline casual labouring & $21 \%$ & $3 \%$ & $0 \%$ & $\dagger$ & $4 \%$ & $6 \%$ & $4 \%$ & \\
\hline not working§ & $8 \%$ & $0 \%$ & $0 \%$ & & $11 \%$ & $14 \%$ & $4 \%$ & \\
\hline \multicolumn{9}{|l|}{ Livestock holding (\%) } \\
\hline cattle & $8 \%$ & $28 \%$ & $17 \%$ & & $7 \%$ & $11 \%$ & $22 \%$ & $\dagger$ \\
\hline cattle + small animal & $38 \%$ & $53 \%$ & $63 \%$ & $*$ & $19 \%$ & $34 \%$ & $22 \%$ & $\dagger$ \\
\hline small animal & $8 \%$ & $0 \%$ & $4 \%$ & & $56 \%$ & $23 \%$ & $26 \%$ & \\
\hline none & $46 \%$ & $19 \%$ & $16 \%$ & & $18 \%$ & $32 \%$ & $30 \%$ & \\
\hline \multicolumn{9}{|l|}{ Land } \\
\hline average land holding (Ha) & 0.21 & 0.67 & 1.24 & $\dagger$ & 0.22 & 0.43 & 0.66 & \\
\hline
\end{tabular}

¥ Wealth ranking ranges from Low (the bottom 30th percentile), Middle (31-70th) to High (71-100th)

$\S$ Due to illness, disability, or old age

$*(p$-value significant at $\leq 0.05) \dagger($ sig. $\leq 0.001)$ 
intensification. The reasons behind this particular observation are explained more in detail in the following sections.

\subsubsection{Sourcing of animal feed}

Farmers in Rwamagana grow forage grass on the boundaries of the land throughout the year, but the majority of the farmers, regardless of their wealth standing, could not feed their animals with grass alone. Especially during the dry seasons, farmers have to supplement feeding either by buying fodder grass and commercial feed or forage from surrounding areas and using crop residues from maize, sorghum and banana extensively. Clear distinctions appear in the feeding strategies adopted by rural farmers in Rwamagana. While all the wealthier farmers could afford to purchase grass, only half of the poor do so. Recurring cash payment for animal feed is usually beyond the reach of many low-income families except during the lactation period when sales revenue from milk can offset the costs. Instead, 75 to 79 percent of the low- and the mid-ranked families collected grass on the wayside to feed their animal.

In the peri-urban village, only one-third of the lowincome families manage to produce enough grass. In comparison, just 19 percent of the wealthy families achieved animal feed self-sufficiency. However, the higher selfsufficiency rate amongst low-income families is not due to their superior production capacity but because of the smaller number of livestock to feed ( 0.57 compared to 1.07 tropical livestock unit, Table 2). Similar to the rural village, families with greater purchasing power overcome the deficit by buying grass from neighbours and using commercial feed such as maize and rice bran, whereas the less well-off turn to foraging and gathering. Regardless of the economic standing, crop residues from maize stalks, sorghum leaves and banana stems are an essential part of the feeding regime for all periurban farmers, and therefore, these crops were grown widely in the area. Although these fibrous by-products provide a bulk of biomass, their nutrient values are low (Kimambo \& Muya, 1991; Preston, 1990). Nonetheless, these were the only affordable feeding sources during the dry seasons for poorer farmers.

\subsection{Diverse livelihood aspirations and multifunctionality of livestock}

Farmers' engagement in crop and livestock farming closely correlated with the farming capacity and socioeconomic standings of the household. However, what the correlations have difficulty unpicking is the multifunctionality of livestock and how their potentials are realised according to livelihood aspirations of the farmers. Using Dorward et al.'s (2009) livelihood aspirations framework, the in-depth qualitative accounts of farmers help discern the underlying determinants that differentiate the propensity for crop-livestock integration of farmers from different economic backgrounds (Appendix 1).

\subsubsection{Cases of low integration}

Many of the economically disadvantaged families cited the high costs of zero-grazing and in-stall rearing as the leading cause of low production and integration. For instance, rearing a big animal in a confined space obliges farmers to commit a constant level of care day in day out, which is both time-consuming and labour-intensive work even if it is just one cow. For instance, a lactating cow needs fresh grass and supplementary feeds and water throughout the day, and when the cow is lactating, farmers have to collect milk and transport it once or twice a day to the market (Habimana, June 4, 2015). Similarly, manure production is continuous, and therefore, farmers have to attend to these chores whether they are profitable or not. That is why, it is not uncommon for farmers to hire a casual labourer even at a small scale of production. For many low-income farmers, this drives up the production costs without significantly improving the milk productivity and output, which can effectively 'trap' farmers into low-yielding production that barely covers its costs. Moreover, many farmers expressed their optimism in the sales value of livestock, considering it profitable whilst not accounting for the current maintenance costs as sunk costs (Nshimiye and Uwase, June 4, 2015).

While milk production is a priority for all cattle owners in the peri-urban village, the differences in total average milk production levels between the groups of farmers varied widely. Several factors of production can explain this discrepancy. For one, the number of cows and more importantly, their lactation cycles are the main determinants. The headcount, however, was more or less a constant: i.e. except for a few exceptions, most farmers who had cattle managed to keep only one cow due to the space constraint in the periurban areas (see TLU in Table 2). Therefore, a more significant production factor was the quantity and quality of feeding. While the middle and top percentile households collected 6.9 (standard deviation, s.d. 3.1) and 8.4 (s.d. 5.2) litres of milk per day in total respectively, the poorer families only managed to get 1.6 (s.d. 0.9) litres, of which half of the milk was sold and the other half was kept for family consumption. Considering the average size of a typical poor household of five people in the peri-urban village (Table 5), the milk consumption rate (let alone selling) would be negligible. Therefore, the prospect for intensification or commercialisation through one-cow production for this group of farmers is unlikely.

In both villages, small livestock such as chicken and goats are essential for savings and covering for periodic expenses 
regardless of their low integration to farming purposes. For instance, chicken is easily convertible for small cash needs, whereas goats are suitable for medium to large expenses such as children's school fees and medical emergencies. In addition, the nutritional aspect of small livestock ownership is crucial for lower-income households. In the rural village, all the lower-income families rearing chicken consumed eggs (but not meat) compared to half of their peri-urban counterparts. This contrast is partly due to an active trade in small livestock and their products in the nearby Rwamagana town and market where lower-income peri-urban households could more easily sell their products, and therefore, prioritise sales over home consumption.

\subsubsection{Cases of high integration}

Farmers in the rural village typically keep about 30 percent of their dairy production for home consumption, sell about 60 percent, and share the remaining milk with neighbours and families. Unlike the peri-urban village, the average milk production level of the lowest-group (6.8 L; s.d. 4.1) is nearly equal to the middle-group farmers' production $(6.9 \mathrm{~L}$; s.d. 4.2), which shows strong motivation and capacity for dairy production even amongst the poorer farmers in the rural village. The high milk yield is in part due to the improved dairy breeds, but more importantly, farmers regarded highly the reproduction management training that they received through the Girinka programme (Mugisha, June 2, 2015). This case demonstrates how even the smallholder farmers could achieve optimal production given the sustained support and training that prioritise the maintenance of a clean and healthy production environment and reproduction cycle.

Besides hard and diligent work, farmers who strive for intensive production cited a harmonious and complementary working relationship and coordination of labour between husband and wife as the backbone of successful crop-livestock integration (Habimana, June 4, 2015). Particularly, for livestock management, consistency in feeding, milking and caring work was vital for ensuring healthy and profitable dairy and manure production. The farmers who could afford also hired additional labourers to take care of the cow, which allowed them to engage in other (productive) activities.

Also, a drive for self-improvement and willingness to experiment (and to take risks) with new production methods were distinct characteristics of the high integrators. For instance, Mugisha was one of the earliest adopters of the crop specialisation and zero grazing practice that the government introduced in 2002. Once he began noticing the increases in crop yields, he voluntarily joined a government initiative of training-the-trainers programme. His willingness to experiment with new production methods prepared him for more ambitious projects such as buying pure dairy breed (Jersey and Friesian) cows and starting a commercial milling business in the village (Mugisha, June 2, 2015). Mugisha obtained capital investment by joining several rotating saving groups, and with that financial leverage, he successfully borrowed and repaid bank loans. Mugisha's one cow dairy production rapidly grew to three in less than two years. The rapid growth of Mugisha's agricultural enterprise is a remarkable example of what at least some rural entrepreneurs can achieve with financial resources and capital investment. A person's tolerance for risk, however, varies individually and a family's aversion to loss is much higher when a family has many dependents (Rusanganwa, 27 May 2015).

\subsubsection{Cases of no integration}

About a quarter of the sampled households in the two villages had no livestock. The sharing of livestock through 'social relations' can potentially strengthen the livestocklivelihood linkages that would enable more low-income families to engage in crop-livestock production and integration. In principle, an asset-transfer or livestock-in-trust contracts such as an indagizanyo arrangement or Girinka cows or goats can be a relief for families who have no means to save or accumulate livestock assets on their own. A typical indagizanyo arrangement obliges the caretaker to complete two successful reproduction cycles (or more) to obtain their share of the female calf or kid goats as the first one belongs to the owner (Nsabimana, June 1, 2015). However, such shared livestock keeping arrangements often fall through due to premature death and infertility, with both parties (but more usually caretaking-party) assuming the loss. The agreements are based on mutual trust and best of intentions, and farmers rarely draft a formal agreement.

Similarly, an inappropriate livestock-in-kind arrangement can put the already vulnerable farmers at higher risk. It was common to find wealthier farmers who have already reached their maximum livestock holding capacity (i.e. one to two cows under zero-grazing regime) lending their heifer and goats to other willing families who do not have the means to invest in livestock (Nshimiye \& Uwase, June 4, 2015). For instance, considering an average of over nine months of the gestation period of a cow, and not to mention the delay when the offspring is a male, the caretaking families have to assume over two years (or more) of risk and costs of feeding and rearing the animal before they can start earning dividends from this contract (Iribagiza, May 2015). The crucial point here is that during this uncertain and prolonged period, farmers' primary concern is the survival of the animal and not the animal's productivity or investment in intensification.

For others, crop-livestock integration and achieving higher productivity were not prioritised. Mutesi is seventy years old, lives in the rural village and she takes care of her 
adult son's cows (Mutesi, May 27, 2015). In the absence of old age security and pension, the son's dairy cow is a valuable livelihood and old age security asset for the elderly mother. Although the productivity may be low, one-cow production generates enough milk for home consumption and some income for basic needs. However, it is unlikely that such a production environment and conditions are conducive for crop-livestock integration let alone intensification. Similarly, in the peri-urban village, Keza and her husband (both working professionals) have two toddlers to take care of, so they decided to buy a cow to produce milk at home (Keza, June 2, 2015). The cow is well fed and the milk yield is plenty, but Keza is not concerned with the milk production beyond the needs for family consumption, and will eventually sell the cow when the children will be of school-age.

Similarly, it is worth highlighting that some families in the upper end of economic standing have no intention of intensifying or further investing in agriculture despite their ample productive asset holdings and financial capacity. Kampire, who lives in the peri-urban village, gradually turned away from farming to start a home brewing business after the death of her husband (Kampire, June 1, 2015). At first, Kampire hired labourers to work on her family farm, but the productivity remained persistently low, so she decided to sell part of the land and converted it into rental accommodation housing and reinvested in her fruit juice processing business. What is remarkable is that Kampire's 'exit' from agriculture and her growing business has contributed to value addition of locally sourced products, and with it, the livelihoods of some of her neighbouring small-scale producers.

\section{Discussion}

\subsection{Multiple livelihood pathways to crop-livestock integration and intensification}

The findings from the household survey assessments indicate that the observed patterns of crop and livestock production differ between the sub-groups of farmers. Furthermore, farmers' qualitative accounts unpack the multifunctionality of livestock and illustrate how family priorities and strategies change in response to opportunities and risks. Together, the household surveys and qualitative interviews of the farmers provide a set of defining characteristics of crop-livestock integrators and their differential capabilities to invest (or not) in intensification. These pathways help us explain what types of production, in which spatial settings (peri-urban versus rural), and for whom such intensification strategies may be beneficial, and why some are unable to adopt the currently promoted agricultural intensification practices. We also discuss what policy responses might be required to better support smallholders' livelihoods for each pathway.

\subsubsection{Pathway 1. Crop-livestock integration for the resource-poor}

The farmers who were unable to keep any livestock represented 26 percent of the total sample population, and the families belonging to this pathway require social security and assistance. Farmland, housing, family labour, cultivation of crops and forage grass and livestock are the fundamental components that make integrated farming possible. The families who have no farm animals lack many (or all) of these assets. Moreover, farmers who are not able to rear livestock are struggling to keep up with production and their farming assets are in a depreciative cycle: tiny plots of land, negative soil fertility balance, lack of labour force (due to ageing, children in school-age or moving away to pursue nonfarming jobs) and inability to afford to intensify production or accumulate savings. A livestock transfer programme such as Girinka cows could be a catalyst for building the initial assets necessary to reverse the poverty cycle (GoR, 2018a). Therefore, provision of start-up assets (such as in-kind or gift of cows) and securing the right to meet their basic needs (especially housing and land) can potentially help broaden the access to a crop-livestock integration pathway (Streeten, 1982). However, having access to or just owning these assets does not necessarily guarantee integration (Kim \& Sumberg, 2015). While the initial transfer of livestock may lift the poor to the first rung of the pathway to asset accumulation, training in crop and livestock farming and rearing and follow-up veterinary support could increase the chances of generating a surplus, as we have seen from the farmers in the rural village but not for the urban counterparts. That is why, beyond the initial asset transfer, a long-term commitment to agricultural training and extension support needs to be followed to safeguard the fragile production environment and to protect the initial asset accumulation stages for the poor (Udo et al., 2011). The farmers' experiences on livelihood shocks and crises also indicated that the development process rarely unfolds linearly. Instead, it fluctuates in response to cyclical and sporadic household expenses and livelihood shocks, undermining the long-term accumulation plan. Such was the case of farmers Nshimiye and Uwase, who successfully managed both crop and livestock farming and accumulated savings over the years but suddenly had to liquidate their assets (land and livestock) to share with their adult sons (Nshimiye \& Uwase, June 4 2015).

Economically vulnerable families rely heavily on small livestock production, especially goats and chicken, as they cost less to maintain, and shorter gestation and reproduction cycles are more advantageous for smallholders who cannot afford to rear cattle. The importance of small ruminants cannot be overlooked as they are uniquely adapted to low resource environments and offer an economic safety net to smallholder farmers. However, despite the sheep and goat 
meat accounting for about a quarter of the total red meat production annually (Shapiro et al., 2017), the government investment plans in crossbreeding and product diversification for indigenous small ruminants such as goats will likely fall short in meeting the projected meat demands. Therefore, improving the extension support for small livestock could serve as both agricultural investment and social protection (Ellis et al., 2009).

New land use and planning legislation to address the needs of (peri-)urban farmers could help build a secure and safe environment for small-scale livestock production and foster agri-business investments in creating more farming jobs for smallholders and landless farmers (Egziabher et al., 1994). However, currently, peri-urban planning and regulations are not conducive to farming activities (GoR, 2018f), and many smallholders who rely on family farming for livelihoods are facing adverse conditions from both within the community and local authority. This is because urban land expansion commonly takes place in arable land, and African countries are expected to experience the highest percentage loss of cropland due to urban development globally by 2030 (Bren d'Amour et al., 2017). In our study sites, farmers are obliged to follow zero-grazing practices, and livestock is raised in household backyards. Often, various issues arise with neighbours due to noise and hygiene concerns, as well as the lack of security and protection against theft of small animals, which are severe impediments for investment amongst peri-urban smallholder farmers. Urbanisation features predominantly in the government's new National Strategy for Transformation plan (GoR, 2017a), which will inevitably cause conflicting priorities for development in peri-urban areas, but there is a strong case for building a more resilient urban food system with marginalised smallholder farmers contributing positively in the urbanisation process (Marshall \& Randhawa, 2017; Peano et al., 2020; Thapa et al., 2010).

\subsubsection{Pathway 2. The one-cow production model}

Sourcing of affordable and high-quality feeding is the biggest problem and a constraint to increasing the intensity of production for smallholder farmers (GoR, 2013). The high cost of zero-grazing makes expansion and intensification of production too expensive for many farmers, and it effectively limits the number of livestock they can keep to one cow and few small animals. Farmers belonging to this category in both study sites are unable to meet their animal feeding demands. The best locally available animal feed solution is to purchase grass from other farmers and supplement the diet with energy-dense cereal brans. These solutions are costly, however, and are beyond the financial means of most smallholders: they could only afford to feed their animals with less nutritious feedstuff such as couch grass from the wayside and untreated crop residues. While sourcing grass this way may seem like a cheap alternative, it is more timeconsuming and labour-intensive to collect sufficient quantity (not to mention nutrient quality) to maintain productivity (Hiernaux et al., 1997).

Farmers in this pathway are running a tight marginal benefit production, and with declining soil fertility and family labour force, they have trouble investing in intensification. However, despite low levels of crop-livestock integration, they are commercially integrated and trade actively (albeit informally). Therefore, more competitive local feed options - other than the commercial feeds such as maize and rice bran - need to be available and affordable to serve smallscale livestock producers (Lukuyu et al., 2009). For instance, establishing community fodder banks and the incorporation of perennial fodder trees into production systems could relieve seasonal peak demands and serve other multifunctional purposes such as soil protection, biofuel, and supplementary income (Kamanzi \& Mapiye, 2012). Without further assistance and support to make a one-cow production system more affordable, most of the farmers under this pathway would find difficulty pursuing and competing in commercially viable intensive dairy production and would only manage to remain in a low-yielding one-cow production system.

\subsubsection{Pathway 3. Small-scale dairy intensification}

Under a zero-grazing regime, the high cost of production compels the farmers to produce more, using fewer resources. The combination of downsizing and genetic improvement of the herd addresses this imperative. The current policy push towards dairy marketing encourages specialised production, and the economy of scale from pasture grazing would yield a much higher margin of profit than zero-grazing production (Ojango et al., 2012). However, the transition from zero-grazing to pasture-grazing requires a substantial capital investment that only the most financially endowed can afford. ${ }^{3}$ Given the lack of availability of and access to pasture land, and the absence of communal grazing tenure or targeted subsidy schemes to promote them, the most frequently aspired and viable intensification pathway in the study sites was dairy specialisation under intensive commercial feeding and zero-grazing.

\footnotetext{
${ }^{3}$ In-depth interviews with large dairy producers from the Rwamagana Milk Collection Centre (MCC) and Cooperative (Murangwa and Twahirwa, March 13 2015, data not shown), revealed that high salary and job security allowed working professionals (and public officials) to take on commercial loans to buy large tracts of land for exclusively grazing and dairy production purposes. These socalled "agro-entrepreneurs" hired labourers and managers to run their operations.
} 
There are several defining characteristics found amongst the highly integrated farmers. The first is a consistent level of high-quality labour in feeding, milking and caring work which ensures healthy and profitable dairy and manure production (Mutimura et al., 2015). With the security of having their property, farmland and family labour to cultivate both staple and cash crops, these farmers were able to purchase and rear livestock successfully. Second, with community savings schemes and commercial capital investment, these farmers could achieve land expansion and production intensification profitably (Kimuyu, 1999). Dairy production and sales of offspring allow the high integrators to save and invest back in agriculture. These farmers manage to grow and accumulate assets from their intensive production and plan to expand gradually through purchasing more land by borrowing (either through informal institutions such as community rotating savings or bank loans) to boost their production and invest in intensification. However, one's willingness to bear risk, such as taking on loans varies individually. Therefore, their success is currently confined to a small segment of the population as their production models are resource-intensive (and high risk).

\subsubsection{Pathway 4. Exit from farming}

For some wealthier farmers, crop-livestock expansion and achieving higher productivity are not a priority. For instance, aspirations for professional work and an interest in other forms of business reduced the families' stake in agriculture. Nonetheless, typically, wealthier families continue to keep one or two cows and cultivate plots. Satisfying food consumption needs is their primary reason for maintaining low crop-livestock integration and not the intensification. These self-sufficient food producers would continue to subsidise low-level of production with their other work wages but would eventually step out from farming once their home consumption needs are met.

On the other hand, a combination of formal and informal sources of income, or 'hybrid livelihoods', reflects the diversification and hybridisation of agrarian livelihoods in periurban economies (Fairbairn et al., 2014). The high, and to some extent, the middle-ranked families, relied on off-farm employment, which reduced their economic dependence on agriculture. In our study, several female-led households decided to diversify away from farming and invest in entrepreneurial activities such as commodity trading and small businesses as an alternative to agricultural intensification. However, their 'exit' from agriculture could also positively generate and induce commercial rural development and investment in value-added transformation and agri-business (Warren, 2002).

\section{Implications for policy and practice and conclusion}

The ways in which Rwandan smallholders integrate crops and livestock in their farming strategies are diverse and dynamic. Accordingly, the ways in which farmers engage with policies promoting intensification vary greatly, as do the impacts on rural households (Clay \& King, 2019). For instance, farmers' capacity in pursuing opportunities are commensurate with their attitude to risk tolerance and competing household resource demands (Bidogeza et al., 2009). Farmers' production and investment decision-making involves a careful balancing of judicious resource management and achieving food self-sufficiency (Bolarinwa et al., 2020; Bucagu et al., 2014). Even with the same type of animal, we found that farmers pursued different production strategies. Only a small but wealthy group of farmers can adopt the forms of intensification promoted in policy, for example, because they are able to supplement the diet with purchased grass or commercial feed or switch to large-scale pasture grazing. On the other hand, achieving commercial viability from intensive dairy production was not a priority for many of the farmers in our study, particularly for families with young children who cared more about household consumption of animal protein than selling at the market. Forgoing intensive production should be viewed as a legitimate decision with potentially positive short-term impacts on health and long-term impacts on the economy. For instance, livestock donations of dairy cows and meat goats from Heifer International in Rwanda had significant positive effects for those households, on child growth and development indicators, and notably, a much greater share of milk was consumed by the families (and children) when they missed markets for selling milk (Rawlins et al., 2014). Therefore, a household's nutritional consideration of dairy production can positively contribute to children's growth and development in rural economies with poor access to dairy markets and where the potential for market development is low (Hoddinott et al., 2015). However, subsidised or donated assets alone are unable to address the more basic, infrastructural and precarious market conditions faced by many smallholders. The success of livestock-in-kind programmes such as these depend on long-term training in animal husbandry and coaching in business management. Even then, the endemic animal feed shortages and high zero-grazing costs of intensive one-cow production are often overlooked by the promoters of livestock-based development initiatives. The idealisation of agricultural intensification and livestock development has long been critiqued in the literature (Ferguson, 1985; Herskovits, 1926), and cattle-centric development models continue to dominate in international donor agencies and nongovernmental projects today for their potential to produce rapid commercial gain (e.g. the 
East Africa Dairy Development), representing to agribusiness, donors and state agencies an attractive technological fix to Africa's agriculture problem, i.e. Green Revolution for Africa (Schurman, 2018). Unfortunately, other potentially significant and viable alternatives for smallholders such as small ruminants and poultry farming are neglected through this highly idealised vision of dairy-centric, rapid economic development (Gass \& Sumberg, 1993).

A deeper, context appropriate understanding of the complex dynamics of crop-livestock integration in smallholder farming systems is essential to underpin policies and programmes that promote inclusive, resource efficient agricultural transitions. Our critical assessment of the conventional policy approach to intensification reveals the need for a broader enquiry that sees beyond 'yield gaps' and 'low productivity'. Other scholars have pointed out that the agricultural intensification transition process does not always lead to increased food security and may adversely affect large numbers of rural inhabitants already facing challenges to meet basic human needs (El Bilali, 2019). Similarly, a recent study in Rwanda evaluated the effect of participation in land consolidation activities (as part of the Crop Intensification Programme) on household diets, nutrition availability, and dietary diversity, and found ambiguous and uneven consumption patterns which compromised the availability of essential micronutrients such as vitamin B12 and lack of protein and fat intake (Del Prete et al., 2019). This is concerning given that farmers are increasingly barred from practising locally resilient and adapted innovations such as intercropping in fear of reprisal and punishment from local authorities for growing crops other than the mandated crops in government-promoted programmes (Huggins, 2009). Such a restrictive policy approach could jeopardise the longterm food security and viability of smallholder productions. Moreover, farmers might miss out from the numerous ecological benefits, synergies and services rendered by an enhanced interaction between crops and livestock resources through nutrients and energy recycling such as improved soil fertility, water storage, pest and disease management, pollination as well as a more resilient and diverse pool of plant species and genetic resources that are vital in an agroecological system (Altieri et al., 2017; Nicholls \& Altieri, 2018). A more flexible approach where farmers could continue to practice diversification strategies such as an improved intercropping system of legume and maize could perform as well as (or even better) than a corresponding government intensification strategy (Isaacs et al., 2016). While a centralised approach can harness the efficiency and accountability in achieving political and macroeconomic objectives through the increasing role of state and commercial actors' involvement in the agriculture sector, it fails to involve farmers directly and so fails to fit with or respond to local needs for livelihood support (Daum \& Birner, 2017). This also undermines genuine participation and grassroots capacity to lead the process of local adaptation against extreme weather, and social and market crises that are more likely to increase with the onset of climate change (Ansoms et al., 2014). Moreover, the top-down, conventional extension programmes stifle local experimentations and social learning and innovation, which are important community resources needed in problem-solving capacity building and resilient food systems (Pamuk et al., 2014).

In many ways, the rural development experience in Rwanda epitomises the broader intensification debate about the transformation of livelihoods of subsistence farmers in sub-Saharan Africa (Kijima et al., 2011; Santpoort, 2020; Vercillo et al., 2020). To that end, our comprehensive investigation of multiple pathways of livelihoods offers four general examples of dynamic paths that question the simplistic assumptions inherent in Green Revolution policies about smallholders' motivations and behaviour, from which policymakers and practitioners could use as entry points for rethinking current intensification strategies and operations to be more effective in addressing the diverse needs of the rural population. Recognising these differences and understanding whether farmers are adopting and pursuing intensive production (or not), and how, is crucial in understanding the contrast between the policy ambition for intensification and the inability of the majority of smallholders to partake in this agenda and adapting policy implementation accordingly. Governments, and other influential organisations, must take into account the diversity and complexity, and the differences in capacities and constraints of different farmers to ensure a more inclusive and resilient agricultural development process to take root in sub-Saharan Africa.

Acknowledgements The authors thank all the farmers and participants for their generous time and trust and the local research partners, especially Noëlla Uwera, Constantine Mukamuhizi, Innocent Maniraguha, and Emmanuel Usabuwera, and the officials at the District of Rwamagana for their invaluable contributions to this study. And special thanks to James Sumberg and Stephen Devereux, who contributed immensely to the first author's doctoral research informing this paper. Detailed feedback from the editor and two anonymous reviewers improved the draft significantly. The research ethics clearance and fieldwork approval were granted by the Research Governance and Ethics Committee at the University of Sussex [ER/SK478/1] and the Ministry of Education of Rwanda [MINEDUC/S\&T/287/2015]. The publication of this work was generously supported by the Economic Social Research Council and South East Network for Social Sciences, UK (ES/T008652/1). The authors' bear full responsibility for any remaining errors.

Funding The publication of this work was supported by the Economic Social Research Council and South East Network for Social Sciences, UK (ES/T008652/1). 
Data availability N/A.

\section{Declarations}

Copyright and license term The authors agree to publish the article (open access) under the Creative Commons Attribution License.

Conflict of interest The authors have no conflicts of interest to declare that are relevant to the content of this article.

Open Access This article is licensed under a Creative Commons Attribution 4.0 International License, which permits use, sharing, adaptation, distribution and reproduction in any medium or format, as long as you give appropriate credit to the original author(s) and the source, provide a link to the Creative Commons licence, and indicate if changes were made. The images or other third party material in this article are included in the article's Creative Commons licence, unless indicated otherwise in a credit line to the material. If material is not included in the article's Creative Commons licence and your intended use is not permitted by statutory regulation or exceeds the permitted use, you will need to obtain permission directly from the copyright holder. To view a copy of this licence, visit http://creativecommons.org/licenses/by/4.0/.

\section{Appendix 1. List of farmers interviewed for in-depth qualitative enquiry}

\section{Rural village}

\begin{tabular}{lllll}
\hline Pseudonym & Gender & Birth year & SE status* & Integration ${ }^{\Delta}$ \\
\hline 1. Gahigi & Male & 1955 & high & high \\
2. Habimana & Male & 1968 & high & high \\
3. Mugisha & Male & 1980 & high & high \\
4. Akaliza & Female & 1990 & high & high \\
5. Garuka & Female & 1953 & high & low \\
6. Isaro & Female & 1980 & high & low \\
7. Keza & Female & 1986 & high & low \\
8. Ngabo & Male & & middle & high \\
9. Mutesi & Female & 1945 & middle & low \\
10. Neza & Female & 1952 & middle & low \\
11. Uwamahoro & Female & 1981 & middle & low \\
12. Nshimiye \& & M \& F & $1949 \& 1981$ & low & low \\
13. Uwase & & & & \\
14. Ingabire & Female & 1957 & low & low \\
15. Rusanganwa & Male & 1951 & low & no \\
16. Shema & Male & 1955 & low & no \\
17. Mutoni & Female & 1982 & low & no \\
\hline
\end{tabular}

\section{Peri-urban village}

\begin{tabular}{lllll}
\hline Pseudonym & Gender & Birth year & SE status* & Integration \\
\hline 1. Amahoro & Female & 1960 & high & high \\
2. Iragena & Female & 1950 & high & low \\
3. Kampire & Female & 1958 & high & low \\
4. Gatete & Male & 1975 & high & none \\
5. Hakizimana & Male & 1947 & middle & low \\
6. Mugwaneza & Male & 1952 & middle & low \\
7. Nsengiyumva & Male & 1960 & middle & low \\
8. Siboyintore & Male & 1960 & middle & low \\
9. Mukobwajana & Female & 1962 & middle & low \\
10. Nkurunziza & Female & 1967 & middle & low \\
11. Uwimbabazi & Female & 1985 & middle & low \\
12. Iribagiza & Female & 1963 & low & none \\
13. Mugabo & Male & & low & none \\
14. Nsabimana & Male & 1983 & low & none \\
\hline
\end{tabular}

* Household socioeconomic standing based on asset index calculation $\Delta$ In theory, having more and larger herd provides, potentially, greater availability of resources required for integration (i.e. high). But in practice, the farmers' aspiration and livelihood context determine whether that integration potential is pursued or not (i.e. none/low/ high)

\section{References}

Altieri, M. A., Nicholls, C. I., \& Montalba, R. (2017). Technological approaches to sustainable agriculture at a crossroads: An agroecological perspective. Sustainability, 9(3), 349.

Altieri, M. A., \& Toledo, V. M. (2011). The agroecological revolution in Latin America: Rescuing nature, ensuring food sovereignty and empowering peasants. Journal of Peasant Studies, 38(3), 587-612.

Ansoms, A. (2008). Striving for growth, bypassing the poor? A critical review of Rwanda's rural sector policies. The Journal of Modern African Studies, 46(1), 1-32.

Ansoms, A., Cioffo, G., Dawson, N., Desiere, S., Huggins, C., Leegwater, M., et al. (2018). The Rwandan agrarian and land sector modernisation: Confronting macro performance with lived experiences on the ground. Review of African Political Economy, 45(157), 408-431.

Ansoms, A., \& McKay, A. (2010). A quantitative analysis of poverty and livelihood profiles: The case of rural Rwanda. Food Policy, 35(6), 584-598.

Ansoms, A., Wagemakers, I., Walker, M. M., \& Murison, J. (2014). Land contestation at the micro scale: Struggles for space in the African marshes. World Development, 54, 243-252.

Ariga, J., Mabaya, E., Waithaka, M., \& Wanzala-Mlobela, M. (2019). Can improved agricultural technologies spur a green revolution in Africa? A multicountry analysis of seed and fertilizer delivery systems. Agricultural Economics, 50, 63-74. 
Barker, J., Hodges, S., \& Walls, F. (2002). Livestock manure production rates and nutrient content. North Carolina agricultural chemicals manual.

Bates, R. H. (1987). Essays on the political economy of rural Africa (Vol. 38). University of California Press.

Beegle, K., De Weerdt, J., Friedman, J., \& Gibson, J. (2010). Methods of household consumption measurement through surveys: Experimental results from Tanzania. The World Bank.

Bernstein, H. (1990). Agricultural 'modernisation' and the era of structural adjustment: Observations on sub-Saharan Africa. Journal of Peasant Studies, 18(1), 3-35.

Bidogeza, J., Berentsen, P., De Graaff, J., \& Lansink, A. O. (2009). A typology of farm households for the Umutara Province in Rwanda. Food Security, 1(3), 321-335.

Bolarinwa, O. D., Ogundari, K., \& Aromolaran, A. B. (2020). Intertemporal evaluation of household food security and its determinants: Evidence from Rwanda. Food Security, 12(1), 179-189.

Booth, D., \& Golooba-Mutebi, F. (2014). Policy for agriculture and horticulture in Rwanda: A different political economy? Development Policy Review, 32(s2), s173-s196.

Boserup, E. (1965). The conditions of agricultural growth: The economics of agrarin change under population pressure. Transaction Publishers.

Bren d'Amour, C., Reitsma, F., Baiocchi, G., Barthel, S., Güneralp, B., Erb, K.-H., et al. (2017). Future urban land expansion and implications for global croplands. Proceedings of the National Academy of Sciences, 114(34), 8939-8944.

Brookfield, H. (1984). Intensification Revisited. Pacific Viewpoint, $25(1), 15-44$.

Brookfield, H. (2001). Intensification, and alternative approaches to agricultural change. Asia Pacific Viewpoint, 42(2-3), 181-192.

Bucagu, C., Vanlauwe, B., Van Wijk, M. T., \& Giller, K. E. (2014). Resource use and food self-sufficiency at farm scale within two agro-ecological zones of Rwanda. Food Security, 6(5), 609-628.

Byiringiro, F., \& Reardon, T. (1996). Farm productivity in Rwanda: Effects of farm size, erosion, and soil conservation investments. Agricultural Economics, 15(2), 127-136.

Chambers, R. (1994). The origins and practice of participatory rural appraisal. World Development, 22(7), 953-969.

Clay, D., Reardon, T., \& Kangasniemi, J. (1998). Sustainable intensification in the highland tropics: Rwandan farmers' investments in land conservation and soil fertility. Economic Development and Cultural Change, 46(2), 351-377.

Clay, N. (2018). Seeking justice in Green Revolutions: Synergies and trade-offs between large-scale and smallholder agricultural intensification in Rwanda. Geoforum, 97, 352-362.

Clay, N., \& King, B. (2019). Smallholders' uneven capacities to adapt to climate change amid Africa's 'green revolution': Case study of Rwanda's crop intensification program. World Development, $116,1-14$.

Conway, G. (1998). The doubly green revolution: food for all in the twenty-first century. Cornell University Press.

Cyamweshi, A. R., Kayumba, J., \& Nabahungu, N. L. (2017). Optimizing fertilizer use within the context of integrated soil fertility management in Rwanda. In Fertilizer use optimization in subSaharan Africa (pp. 164-176). CABI.

Daum, T., \& Birner, R. (2017). The neglected governance challenges of agricultural mechanisation in Africa-insights from Ghana. Food Security, 9(5), 959-979.

Dawson, N. (2015). Bringing context to poverty in rural Rwanda: added value and challenges of mixed methods approaches. In Mixed Methods Research in Poverty and Vulnerability (pp. 61-86). Springer.

Dawson, N., Martin, A., \& Sikor, T. (2016). Green revolution in subSaharan Africa: Implications of imposed innovation for the wellbeing of rural smallholders. World Development, 78, 204-218.
Del Prete, D., Ghins, L., Magrini, E., \& Pauw, K. (2019). Land consolidation, specialization and household diets: Evidence from Rwanda. Food Policy, 83, 139-149.

Desiere, S., Staelens, L., \& D'Haese, M. (2016). When the data source writes the conclusion: Evaluating agricultural policies. The Journal of Development Studies, 52(9), 1372-1387.

Dixon, J., Gulliver, A., \& Gibbon, D. (2001). Improving farmers' livelihoods in a changing world. Rome and Washington DC: FAO/ World Bank.

Djurfeldt, A. A., Djurfeldt, G., Hillbom, E., Isinika, A. C., Joshua, M. D. K., Kaleng'a, W. C., et al. (2019). Is there such a thing as sustainable agricultural intensification in smallholder-based farming in sub-Saharan Africa? Understanding yield differences in relation to gender in Malawi, Tanzania and Zambia. Development Studies Research, 6(1), 62-75.

Dorward, A., Anderson, S., Bernal, Y. N., Vera, E. S., Rushton, J., Pattison, J., et al. (2009). Hanging in, stepping up and stepping out: Livelihood aspirations and strategies of the poor. Development in Practice, 19(2), 240-247.

Dorward, A., Anderson, S., Clark, S., Keane, B., \& Moguel, J. (2001). Asset functions and livelihood strategies: a framework for propoor analysis. Policy and Practice. Imperial College at Wye.

Drechsel, P., Steiner, K. G., \& Hagedorn, F. (1996). A review on the potential of improved fallows and green manure in Rwanda. Agroforestry Systems, 33(2), 109-136.

Droppelmann, K. J., Snapp, S. S., \& Waddington, S. R. (2017). Sustainable intensification options for smallholder maize-based farming systems in sub-Saharan Africa. Food Security, 9(1), 133-150.

Egziabher, A. G., Lee-Smith, D., Maxwell, D. G., Memon, P. A., Mougeot, L. J. A., \& Sawio, C. J. (1994). Cities feeding people: an examination of urban agriculture in East Africa. International Development Research Centre (IDRC).

El Bilali, H. (2019). Research on agro-food sustainability transitions: A systematic review of research themes and an analysis of research gaps. Journal of Cleaner Production, 221, 353-364.

Ellis, F. (1993). Peasant economics: Farm households in agrarian development (Vol. 23). Cambridge University Press.

Ellis, F., Devereux, S., \& White, P. (2009). Social protection in Africa. Edward Elgar Publishing.

Evenson, R. E., \& Gollin, D. (2003). Assessing the impact of the Green Revolution, 1960 to 2000. Science, 300(5620), 758-762.

Fairbairn, M., Fox, J., Isakson, S. R., Levien, M., Peluso, N., Razavi, S., et al. (2014). Introduction: New directions in agrarian political economy. Journal of Peasant Studies, 41(5).

FAO (2001). Mixed crop-livestock farming: A review of traditional technologies based on literature and field experiences. In $\mathrm{H}$. Schiere, \& L. Katere (Eds.), (Vol. Animal Production and Health Paper). Rome: Food and Agriculture Organization.

FAOSTAT (2020). Land use indicators. http://www.fao.org/faostat/en/. Accessed 12 July 2019.

Ferguson, J. (1985). The bovine mystique: power, property and livestock in rural Lesotho. Man, 647-674.

Filmer, D., \& Pritchett, L. H. (2001). Estimating wealth effects without expenditure data - or tears: An application to educational enrollments in states of India. Demography, 38(1), 115-132.

Gass, G., \& Sumberg, J. (1993). Intensification of livestock production in Africa: Experience and issues. In Overseas Development Group (Ed.). University of East Anglia, Norwich, UK.

Glover, D., Sumberg, J., Ton, G., Andersson, J., \& Badstue, L. (2019). Rethinking technological change in smallholder agriculture. Outlook on Agriculture, 48(3), 169-180.

GoR. (2000). Rwanda Vision 2020. Kigali: Ministry of Finance and Economic Planning.

GoR. (2005). Organic Law determining the use and management of land in Rwanda. $N^{\circ} 08 / 2005$ of 14/07/2005. Kigali: The Official Gazette of the Republic of Rwanda. 
GoR (2007). Crop Intensification Program (CIP). https://www.minagri. gov.rw/. Accessed 6 October 2020.

GoR. (2011). The Third Integrated Household Living Conditions Survey (EICV 3). Thematic Report - Agriculture. Kigali: National Institute of Statistics of Rwanda.

GoR. (2012). Rwanda: Comprehensive food security and vulnerability analysis and nutrition survey. VAM Food Security Analysis. Kigali: National Institute of Statistics of Rwanda, Ministry of Agriculture and Animal Resources, UN World Food Programme.

GoR. (2013). National Dairy Strategy. Kigali: Ministry of Agriculture and Animal Resources.

GoR. (2015a). The Fourth Integrated Household Living Conditions Survey (EICV 4). Thematic Report - Agriculture. Kigali: National Institute of Statistics of Rwanda.

GoR. (2015b). Seasonal agricultural survey 2015: Season A report. Kigali: National Institute of Statistics of Rwanda.

GoR. (2016). Seasonal agricultural survey 2016: Season A report. Kigali: National Institute of Statistics of Rwanda.

GoR. (2017a). 7 Years Government Programme: National Strategy for Transformation (NST1) 2017-2024. Kigali: Ministry of Finance and Economic Planning.

GoR. (2017b). Seasonal agricultural survey 2017: Season A report. Kigali: National Institute of Statistics of Rwanda.

GoR. (2018a). Assessing Girinka Programme (2006-2016): Citizen perspectives. Kigali: Rwanda Governance Board.

GoR. (2018b). The Fifth Integrated Household Living Conditions Survey (EICV 5). In NISR; (Ed.), Poverty Profile Report 2016/17. National Institute of Statistics of Rwanda.

GoR. (2018c). National Agriculture Policy. Kigali: Ministry of Agriculture and Animal Resources.

GoR. (2018d). Seasonal agricultural survey 2018: Season A report. Kigali: National Institute of Statistics of Rwanda.

GoR. (2018e). Strategic Plan for Agriculture Transformation 2018-24. Kigali: Ministry of Agriculture and Animal Resources.

GoR. (2018f). Urbanisation \& Rural Settlement. Sector Strategic Plan for National Strategy for Transformation (Vol. 2018/19-23/24). Ministry of Infrastructure.

GoR. (2019). Seasonal agricultural survey 2019: Season A report. National Institute of Statistics of Rwanda.

GoR. (2020). Seasonal agricultural survey 2020: Season A report. National Institute of Statistics of Rwanda.

GoR. (2021). Horticulture sector. https://rdb.rw/export/export/productsdirectory/horticulture-sector/. Accessed 21 July 2021.

Griffin, K. B. (1979). The political economy of agrarian change: An essay on the Green Revolution. MacMillan.

Headey, D. D., \& Jayne, T. S. (2014). Adaptation to land constraints: Is Africa different? Food Policy, 48, 18-33.

Heinen, S. (2021). Rwanda's Agricultural Transformation Revisited: Stagnating Food Production, Systematic Overestimation, and a Flawed Performance Contract System. SOAS Department of Economics Working Paper No. 242. London: SOAS University of London.

Herskovits, M. J. (1926). The cattle complex in East Africa. American Anthropologist, 28(1), 230-272.

Hiernaux, P., Fernández-Rivera, S., Schlecht, E., Turner, M., \& Williams, T. O. (1987). Crop residue/livestock relationships. In Livestockmediated nutrient transfers in Sahelian agro-ecosystems, 1997. Niamey, Niger: International Crops Research Institute for the Semi-Arid Tropics (ICRISAT)

Hoddinott, J., Headey, D., \& Dereje, M. (2015). Cows, missing milk markets, and nutrition in rural Ethiopia. The Journal of Development Studies, 51(8), 958-975.

Huggins, C. (2009). Agricultural policies and local grievances in rural Rwanda. Peace Review, 21(3), 296-303.

Huggins, C. (2014). 'Control Grabbing' and small-scale agricultural intensification: Emerging patterns of state-facilitated 'agricultural investment' in Rwanda. Journal of Peasant Studies, 41(3), 365-384.

Ingelaere, B. (2014). What's on a peasant's mind? Experiencing RPF state reach and overreach in post-genocide Rwanda (2000-10). Journal of Eastern African Studies, 8(2), 214-230.

Isaacs, K. B., Snapp, S. S., Chung, K., \& Waldman, K. B. (2016). Assessing the value of diverse cropping systems under a new agricultural policy environment in Rwanda. Food Security, 8(3), 491-506.

Jayne, T. S., Chamberlin, J., \& Headey, D. D. (2014). Land pressures, the evolution of farming systems, and development strategies in Africa: A synthesis. Food Policy, 48, 1-17.

Kamanzi, M., \& Mapiye, C. (2012). Feed inventory and smallholder farmers' perceived causes of feed shortage for dairy cattle in Gisagara District. Rwanda. Tropical Animal Health and Production, 44(7), 1459-1468.

Kijima, Y., Otsuka, K., \& Sserunkuuma, D. (2011). An inquiry into constraints on a green revolution in Sub-Saharan Africa: The case of NERICA rice in Uganda. World Development, 39(1), $77-86$.

Kim, S. K., \& Sumberg, J. (2015). Assets, 'Asset-ness' and Graduation. IDS Bulletin, 46(2), 124-133.

Kim, S. K., Tiessen, K. H., Beeche, A. A., Mukankurunziza, J., \& Kamatari, A. (2013). Soil Fertility and Manure ManagementLessons from the Knowledge, Attitudes, and Practices of Girinka Farmers in the District of Ngoma. Rwanda. Agroecology and Sustainable Food Systems, 37(6), 631-658.

Kimambo, A. E., \& Muya, H. (1991). Rumen degradation of dry matter and organic matter of different parts of the banana plant. Livestock Research for Rural Development, 3(3), 35-40.

Kimuyu, P. K. (1999). Rotating saving and credit associations in rural East Africa. World Development, 27(7), 1299-1308.

Kuria, A. W., Barrios, E., Pagella, T., Muthuri, C. W., Mukuralinda, A., \& Sinclair, F. L. (2019). Farmers' knowledge of soil quality indicators along a land degradation gradient in Rwanda. Geoderma Regional, 16, e00199.

Lal, R. (2015). Restoring soil quality to mitigate soil degradation. Sustainability, 7(5), 5875-5895.

LandLinks. (2017). Rwanda. https://land-links.org/country-profile/ rwanda/. Accessed 11 July 2021.

Lukuyu, B. A., Kitalyi, A., Franzel, S., Duncan, A. J., \& Baltenweck, I. (2009). Constraints and options to enhancing production of high quality feeds in dairy production in Kenya, Uganda and Rwanda. ICRAF Working Paper No.95. Nairobi, Kenya: World Agroforestry Centre.

Marshall, F., \& Randhawa, P. (2017). India's peri-urban frontier: Ruralurban transformations and food security. Working Paper. London: International Institute for Environment and Development (IIED).

Mati, B. M. (2006). Overview of water and soil nutrient management under smallholder rain-fed agriculture in East Africa (Vol. 105). International Water Management Institute (IWMI).

McIntire, J., Bourzat, D., \& Prabhu, P. (1992). Crop-livestock interaction in sub-Saharan Africa. Washington, DC: World Bank.

McMichael, P. (2009). Banking on agriculture: A review of the World Development Report 2008. Journal of Agrarian Change, 9(2), 235-246.

Mkandawire, T. (2014). The spread of economic doctrines and policymaking in postcolonial Africa. African Studies Review, 57(1), 171-198.

Moorsom, T. L., Rao, S., Gengenbach, H., \& Huggins, C. (2020). Food security and the contested visions of agrarian change in Africa. Canadian Journal of Development Studies/revue Canadienne D'études Du Développement, 41(2), 212-223.

Mutimura, M., Ebong, C., Rao, I. M., \& Nsahlai, I. V. (2015). Factors influencing current and future prospects for intensive dairy 
production in Rwanda. Paper presented at the The 23rd International Grassland Congress - Sustainable use of grassland resources for forage production, biodiversity and environmental protection, New Delhi, India,

Nicholls, C. I., \& Altieri, M. A. (2018). Pathways for the amplification of agroecology. Agroecology and Sustainable Food Systems, 42(10), 1170-1193.

Njuki, J., Poole, J., Johnson, N., Baltenweck, I., Pali, P., Lokman, Z., et al. (2011). Gender, livestock and livelihood indicators (p. 40). International Livestock Research Institute (ILRI).

Ojango, J. M., Kinuthia, E., \& Baltenweck, I. (2012). Cost of milk production in Rwanda. In EADD (Ed.), East Africa Dairy Development. Heifer International.

Otsuka, K., \& Muraoka, R. (2017). A green revolution for sub-Saharan Africa: Past failures and future prospects. Journal of African Economies, 26(suppl_1), i73-i98.

Pamuk, H., Bulte, E., \& Adekunle, A. A. (2014). Do decentralized innovation systems promote agricultural technology adoption? Experimental evidence from Africa. Food Policy, 44, 227-236.

Parrott, N., \& Marsden, T. (2002). The Real Green Revolution Organic and Agroecological Farming in the South. Greenpeace Environmental Trust.

Patel, R. (2013). The long green revolution. Journal of Peasant Studies, 40(1), 1-63.

Peano, C., Massaglia, S., Ghisalberti, C., \& Sottile, F. (2020). Pathways for the amplification of agroecology in African sustainable urban agriculture. Sustainability, 12(7), 2718.

Pearse, A. (1980). Seeds of plenty, seeds of want: social and economic implications of the green revolution. In P. Utting (Ed.), Revisiting Sustainable Development (2015) (Vol. III). Geneva: UNRISD.

Pingali, P. L. (2012). Green revolution: Impacts, limits, and the path ahead. Proceedings of the National Academy of Sciences, 109(31), 12302-12308.

Pingali, P. L., \& Rosegrant, M. W. (1995). Agricultural commercialization and diversification: Processes and policies. Food Policy, 20(3), 171-185.

Pinstrup-Andersen, P., \& Hazell, P. (1985). The impact of the Green Revolution and prospects for the future. Food Reviews International, 1(1), 1-25.

Preston, T. R. (1990). Future strategies for livestock production in tropical third world countries. Ambio, 390-393.

Pretty, J., Benton, T. G., Bharucha, Z. P., Dicks, L. V., Flora, C. B., Godfray, H. C. J., et al. (2018). Global assessment of agricultural system redesign for sustainable intensification. Nature Sustainability, 1(8), 441-446.

Rawlins, R., Pimkina, S., Barrett, C. B., Pedersen, S., \& Wydick, B. (2014). Got milk? The impact of Heifer International's livestock donation programs in Rwanda on nutritional outcomes. Food Policy, 44, 202-213.

Reyntjens, F. (2018). Understanding Rwandan politics through the longue durée: From the precolonial to the post-genocide era. Journal of Eastern African Studies, 12(3), 514-532.

Ruthenberg, H., MacArthur, J. D., Zandstra, H., \& Collinson, M. P. (1980). Farming systems in the tropics. Clarendon Press.

Ruttan, V. W., \& Hayami, Y. (1984). Toward a theory of induced institutional innovation. The Journal of Development Studies, 20(4), 203-223.

Sahn, D. E., \& Stifel, D. (2003). Exploring alternative measures of welfare in the absence of expenditure data. Review of Income and Wealth, 49(4), 463-489.

Santpoort, R. (2020). The drivers of maize area expansion in sub-Saharan Africa. How policies to boost maize production overlook the interests of smallholder farmers. Land, 9(3), 68.
Schurman, R. (2018). Micro(soft) managing a 'green revolution'for Africa: The new donor culture and international agricultural development. World Development, 112, 180-192.

Scoones, I. (2009). Livelihoods perspectives and rural development. Journal of Peasant Studies, 36(1), 171-196.

Scoones, I., \& Wolmer, W. (2002). Pathways of change in Africa: crops, livestock \& livelihoods in Mali, Ethiopia \& Zimbabwe: James Currey Ltd.

Shapiro, B. I., Gebru, G., Desta, S., \& Nigussie, K. (2017). Rwanda livestock master plan. ILRI.

Stone, G. D., Brush, S., Busch, L., Cleveland, D. A., Dove, M. R., Herring, R. J., et al. (2007). Agricultural deskilling and the spread of genetically modified cotton in Warangal. Current Anthropology, 48(1), 67-103.

Streeten, P. (1982). First things first: meeting basic human needs in the developing countries. The World Bank.

Struik, P. C., Kuyper, T. W., Brussaard, L., \& Leeuwis, C. (2014). Deconstructing and unpacking scientific controversies in intensification and sustainability: Why the tensions in concepts and values? Current Opinion in Environmental Sustainability, 8, 80-88.

Thapa, S., Marshall, F., \& Stagl, S. (2010). Understanding peri-urban sustainability: the role of the resilience approach. STEPS Working Paper (Vol. 38). Brighton: The Social, Technological and Environmental Pathways to Sustainability Centre.

The Abuja Summit. (2006). Abuja Declaration on Fertilizer for the African Green Revolution. In African Development Bank Group (Ed.). Abuja, Nigeria: New Partnership for Africa's Development (NEPAD).

The Malabo Summit. (2014). The Malabo Declaration on Accelerated Agricultural Growth and Transformation for Shared Prosperity and Improved Livelihoods. In African Union (Ed.). Malabo, Equatorial Guinea: NEPAD.

Udo, H., Aklilu, H., Phong, L., Bosma, R., Budisatria, I., Patil, B., et al. (2011). Impact of intensification of different types of livestock production in smallholder crop-livestock systems. Livestock Science, 139(1-2), 22-29.

Van Damme, J., Ansoms, A., \& Baret, P. V. (2014). Agricultural innovation from above and from below: Confrontation and integration on Rwanda's hills. African Affairs, 113(450), 108-127.

Vanlauwe, B., Coyne, D., Gockowski, J., Hauser, S., Huising, J., Masso, C., et al. (2014). Sustainable intensification and the African smallholder farmer. Current Opinion in Environmental Sustainability, 8, 15-22.

Vercillo, S., Weis, T., \& Luginaah, I. (2020). A bitter pill: Smallholder responses to the new green revolution prescriptions in northern Ghana. International Journal of Sustainable Development \& World Ecology, 27(6), 565-575.

Verwimp, P. (2002). Agricultural policy, crop failure and the Ruriganiza Famine (1989) in Southern Rwanda: A pre-lude to genocide? In Center for Economic Studies (Ed.), Discussion Paper Series (02.07). Katholieke Universiteit Leuven.

Wanmali, S., \& Bayliss-Smith, T. (1984). Understanding green revolutions: agrarian change and development in South Asia. Cambridge University Press.

Warren, P. (2002). Livelihoods diversification and enterprise development: An initial exploration of concepts and issues. Livelihood Support Program (LSP) Working Paper (Vol. 4). UN Food and Agriculture Organization.

World Bank. (2008). World development report 2008: Agriculture for development.

World Bank. (2014). Transformation of agriculture sector program Phase 3 Program appraisal document.

World Bank Data. (2020). Population density (people per sq. km of land area) - Rwanda. https://data.worldbank.org/indicator/. Accessed 1 September 2021. 


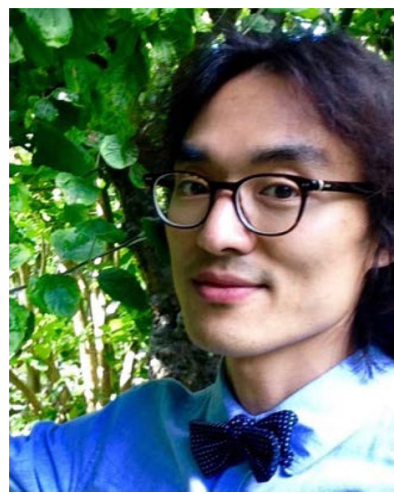

Sung Kyu Kim is a Lecturer at the Science Policy Research Unit, University of Sussex Business School. His work focuses on the role of smallholder farming in the future of agriculture in the context of global development and food security. His research explores the dynamic processes and multifaceted nature of farming and livelihood practices of smallholder farmers by using mixed methods and pathways approach. His interest in the sustainable food system has led to research and fieldwork in smallscale farming regions in Rwanda, Senegal, the Gambia, Haiti as well as in Canada, Italy and the UK.

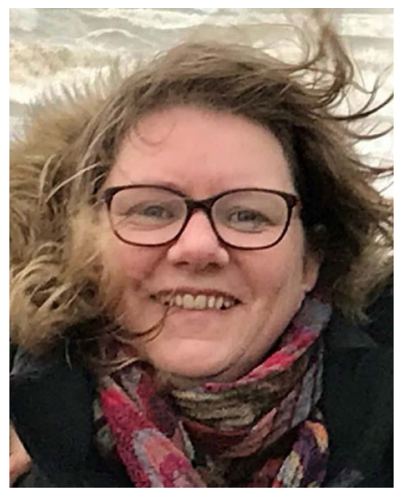

Fiona Marshall is a Professor of Environment and Development at the Science Policy Research Unit, University of Sussex Business School. Her research spans environmental change, food systems, international development and science and technology policy studies. She has over 25 years' experience in the design, management and implementation of transdisciplinary research initiatives which bridge the natural, social and physical sciences and engage with local communities, NGOs and policymakers.

Fiona has extensive field experience in the global South, working in collaboration with partners in Eastern and Southern Africa, South Asia and Latin America. Diverse case studies examine pathways to sustainability and synergies and trade-offs across SDGs, including investigations into the interrelationships between natural resource management (policy and practice) and poverty alleviation in complex, diverse riskprone environments.

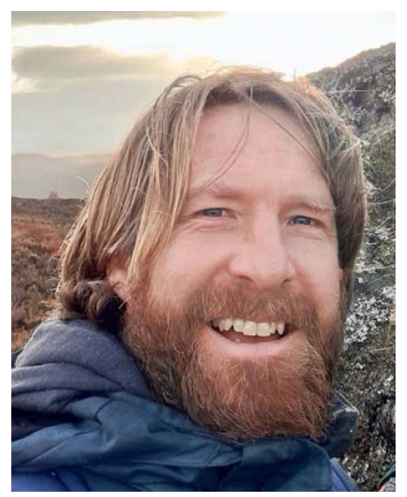

Neil Dawson is an environmental social scientist focused on applied research into poverty, wellbeing and environmental justice in remote rural areas. His work in sub-Saharan Africa, Asia and South America covers the three interrelated themes of biodiversity conservation, agriculture and climate change. He is a research fellow with the Global Environmental Justice Group at the University of East Anglia in the UK, Chair of the Human Wellbeing and Sustainable Livelihoods Theme for IUCN CEESP

(The International Union for the Conservation of Nature Commission on Environmental, Economic \& Social Policy), and a postdoc at the European School of Political and Social Sciences in Lille, France. 